\title{
Technological spillovers and industrial growth in Chinese regions
}

Citation for published version (APA):

Wang, L., Meijers, H. H. M., \& Szirmai, A. (2013). Technological spillovers and industrial growth in Chinese regions. Maastricht University. UNU-MERIT Working Papers No. 044

Document status and date:

Published: 01/01/2013

Document Version:

Publisher's PDF, also known as Version of record

\section{Please check the document version of this publication:}

- A submitted manuscript is the version of the article upon submission and before peer-review. There can be important differences between the submitted version and the official published version of record.

People interested in the research are advised to contact the author for the final version of the publication, or visit the DOI to the publisher's website.

- The final author version and the galley proof are versions of the publication after peer review.

- The final published version features the final layout of the paper including the volume, issue and page numbers.

Link to publication

\footnotetext{
General rights rights.

- You may freely distribute the URL identifying the publication in the public portal. please follow below link for the End User Agreement:

www.umlib.nl/taverne-license

Take down policy

If you believe that this document breaches copyright please contact us at:

repository@maastrichtuniversity.nl

providing details and we will investigate your claim.
}

Copyright and moral rights for the publications made accessible in the public portal are retained by the authors and/or other copyright owners and it is a condition of accessing publications that users recognise and abide by the legal requirements associated with these

- Users may download and print one copy of any publication from the public portal for the purpose of private study or research.

- You may not further distribute the material or use it for any profit-making activity or commercial gain

If the publication is distributed under the terms of Article $25 \mathrm{fa}$ of the Dutch Copyright Act, indicated by the "Taverne" license above, 


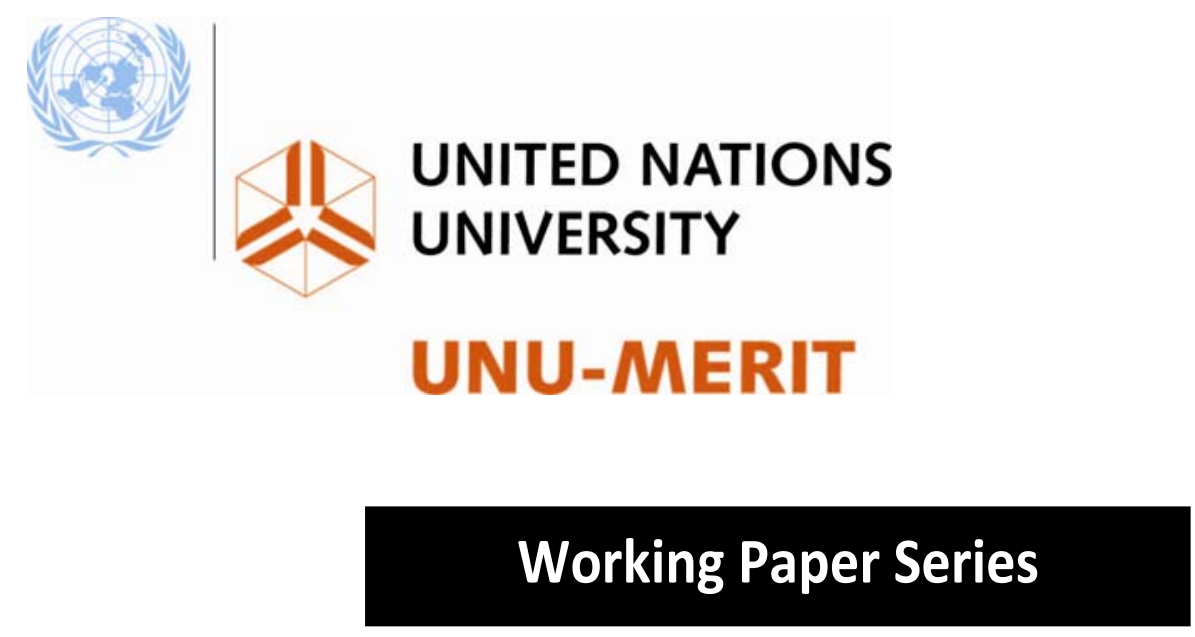

\#2013-044

Technological spillovers and industrial growth in Chinese regions Lili Wang, Huub Meijers and Adam Szirmai

Maastricht Economic and social Research institute on Innovation and Technology (UNU-MERIT) email: info@merit.unu.edu | website: $\underline{\text { http://www.merit.unu.edu }}$

Maastricht Graduate School of Governance (MGSoG)

email: info-governance@maastrichtuniversity.nl | website: http://mgsog.merit.unu.edu

Keizer Karelplein 19, 6211 TC Maastricht, The Netherlands

Tel: (31) (43) 388 4400, Fax: (31) (43) 3884499 
UNU-MERIT Working Papers

ISSN 1871-9872

Maastricht Economic and social Research Institute on Innovation and Technology, UNU-MERIT

Maastricht Graduate School of Governance

MGSoG

UNU-MERIT Working Papers intend to disseminate preliminary results of research carried out at UNU-MERIT and MGSoG to stimulate discussion on the issues raised. 


\title{
Technological Spillovers and Industrial Growth in Chinese Regions
}

\author{
Lili Wang*, Huub Meijers and Adam Szirmai \\ UNU-MERIT and Maastricht University, the Netherlands
}

\begin{abstract}
This paper focuses on the role of interregional technology spillovers in the process of industrial growth in Chinese regions in the period 1990-2005. Inflows of FDI increased rapidly from 1990 till 1998, slowing down thereafter. Domestic R\&D investment accelerated after 1998. Regional industrial growth benefits from both interregional R\&D spillovers and after 1998 from international FDI spillovers. However, in contrast to R\&D spillovers, FDI spillovers contribute conditionally, mainly in areas where local $R \& D$ stocks are high enough. Interestingly, indirect interregional FDI spillover effects are negative. Foreign investment in one region attracts resources from regions with less FDI, thus having a negative influence on growth of industrial output in neighbouring regions.
\end{abstract}

\section{Keywords}

Technological spillovers; Interregional spillovers; R\&D; Foreign direct investment; Industrial growth; Chinese industry

JEL Classification: F43, O14, O33, R11, R12

* Corresponding Author: Lili Wang, UNU-MERIT and Maastricht University, Keizer Karelplein 19, 6211 TC, Maastricht, The Netherlands. Tel:+ 31 (0)43-3884456 Email Wang@merit.unu.edu. 


\section{Introduction}

In modern growth theory technological spillovers are amongst the key sources of growth. In the Gerschenkronian tradition, one of the important potential sources of catch up in technologically backward economies is international technology and knowledge spillovers from the advanced economies. A similar reasoning can be applied to regions. Technologically more backward regions can profit from spillovers from technologically more advanced regions. In a previous paper (Wang and Szirmai, 2013), we find that in the long run there is a tendency towards regional convergence in China. In the present paper, we address the question whether technological spillovers from regions with high levels of FDI and R\&D play a role as drivers of regional growth in neighbouring regions. We distinguish between interregional R\&D spillovers and interregional FDI spillovers. R\&D spillovers represent the interregional effects of domestic investment in knowledge; FDI spillovers represent the interregional effects of international technology spillovers. We also examine the direct effects of R\&D and international technology spillovers.

Research and development activities (R\&D) have both direct and indirect effects on economic performance. The direct effect is that a firm that carries out $R \& D$ will benefit from the innovation of its products, processes, materials or organization. This helps a firm to increase its market share and profits. The indirect effect refers to the possibility that firms can imitate and learn from technological knowledge developed by other firms, no matter whether it is embodied in new products, processes or organizational routines. Such technological spillovers (externalities) result in increasing returns to scale at the macro level, even if technological investment in one firm might have decreasing marginal returns and constant returns to scale (see Mohnen, 1996, for a survey of R\&D externalities).

Technological spillovers play a crucial role in catch-up and convergence at both regional and national levels. The lagging regions or countries benefit from applying new technologies developed by the technological leaders, without having to bear the full costs and risks of developing these technologies. Due to their access to these kinds of technologies, lagging regions or countries can sometimes take large leaps in economic development. This is referred to as the advantages of backwardness (Gerschenkron, 1962; Abramovitz, 1989, see also the discussion in Szirmai, 2012). 
In two previous papers (Wang and Szirmai, $2008 \&$ 2013), we provide a first analysis of industrial growth performance in China. The annual growth rate of industrial labour productivity was 8.3 per cent between 1992 and 1997 and 19.2 percent between 1997 and 2002 (Wang and Szirmai, 2008). Using the coefficient of variation of GDP per worker, we found that in the long run there was a process of regional convergence in industrial productivity, with the lagging regions growing more rapidly than the leading regions. Regional inequality in 2005 was some 30 per cent less than in 1978.

In this paper, we focus on the growth of industrial value added in 29 Chinese regions ${ }^{1}$ and examine the extent to which knowledge spillovers play a role in the growth of regional output. ${ }^{2}$ With regard to regional spillovers, one set of studies (including this paper) focuses on knowledge spillovers between regions; the other set of studies examines output spillovers (Groenewold et al., 2006; Zhang and Felmingham, 2002) ${ }^{3}$. Concerning the sources of knowledge spillovers in Chinese regions, we distinguish between interregional and international sources of knowledge spillovers. The former concept refers to $\mathrm{R} \& \mathrm{D}$ inputs in Chinese regions; the latter refers to international knowledge embodied in foreign direct investment (FDI) in Chinese regions. The analysis makes use of a unique newly constructed dataset of regional capital stocks (Wang and Szirmai, 2012).

In this paper we explore the following questions:

1. How important are international FDI spillovers for regional industrial growth?

2. How important are interregional FDI spillovers for regional industrial growth?

3. How important is intraregional R\&D for regional industrial growth?

4. How important are interregional $R \& D$ spillovers for regional industrial growth?

\footnotetext{
${ }^{1}$ There are totally 31 provincial-level regions in mainland of China. Tibet is not included in our analysis due to lack of data. Our analysis covers 30 regions. Chongqing- which was part of Sichuan in early years and only has most of its data available from 1996 onwards - is combined with Sichuan. Therefore we have 29 regional units in total.

${ }^{2}$ We do not explicitly address growth in backward regions in this paper, but as FDI and R\&D are typically concentrated in more advanced regions, the analysis has important implications for regional catch up trends.

${ }^{3}$ This branch focuses on the inter-regional growth spillovers, not technological spillovers.
} 
The paper is organized as follows. Section 2 provides a review of the relevant theoretical and empirical literature concerning knowledge spillovers. Section 3 provides a discussion of the data. Section 4 presents our methodology, data and empirical results. Conclusions are drawn in section 5.

\section{Review of the literature}

\subsection{Spillover Types and Contributions}

Griliches (1979 \& 1992) distinguished two different types of technological spillovers, namely rent spillovers and knowledge spillovers. The former occur when technologyintensive inputs are acquired by firms or industries at a price less than "their full quality price", while the latter refers to knowledge flow which takes place without any business transactions occurring. Such pure knowledge spillovers can take place through a variety of channels, such as imitation of innovations, mobility of skilled personnel, reverse engineering, using freely available "open” or public knowledge, infringing on patents, access to international scientific literature, FDI or communication between R\&D personnel. The term technology spillover is often used for pure knowledge spillovers.

Coe and Helpman (1995) and Jiang et al. (2010) find that R\&D investment in G7 countries has positive spillover effects for their trade partners, including China. Coe and Helpman (1995) suggest the social returns to R\&D (including the effects of international technology spillovers) are larger than the private returns (the returns to R\&D within a given countries). The following studies also demonstrate different kinds of significant technology spillovers: intra-industry spillovers (Bernstein and Nadiri, 1989) ${ }^{4}$, inter-industry spillovers (Girma and Wakelin, 2007) ${ }^{5}$ and regional spillovers (Funke and Niebuhr, 2005) ${ }^{6}$.

\footnotetext{
${ }^{4}$ Their studied industries include Chemicals, Petroleum, Machinery and Instruments.

${ }^{5}$ They use plant-level data in the electronics sector in the UK.

${ }^{6}$ They find that regional growth in 71 regions in western Germany is positively influenced by the R\&D activities in nearby regions.
} 
FDI spillovers, as a type of international knowledge spillovers, have been regarded as a very important source of knowledge in developing countries, since foreign investment in developing countries, embodies advanced technologies and provides access to the knowledge base created by $R \& D$ in the advanced economies. The Chinese government provides considerable privileges to foreign firms in order to attract foreign investment to China. This assumes that the positive effects of FDI on economic growth are assumed to outweigh its possible negative effects (Liu and Wang, 2003; Liu and Buck, 2007). The contribution of FDI to the Chinese economy not only results from its contribution to capital accumulation, productivity and exports but also from technological spillovers. There are two main channels by which local firms can benefit from FDI-related technological spillovers. One is through imitating products developed by foreign companies, given that local firms can easily learn from the new design of a market product. The other channel is through mobility of employment. Employees trained or hired by foreign companies can bring knowledge to local firms when they switch jobs. ${ }^{7}$ Besides positive contributions the entry of foreign affiliates through FDI may also have negative effects on domestic companies, if multinational companies reduce the market shares of domestic firms, take away talented employees from domestic companies and limit technology transfers and spillovers. Branstetter and Feenstra (2002) argue that Chinese state-owned enterprises (SOEs) are more likely to oppose FDI than private firms because the entry of foreign firms brings more competition and threats to SOEs. However, the newly established Anti-Monopoly Law - which came into effect on August 1, 2008- includes a prohibition on abuse of dominance by monopolies and promotes a free market, therefore, the volume of FDI probably will not be determined by the SOEs.

With regard to FDI spillover effects, the results are mixed. From the ownership perspective, some authors find that foreign investment is beneficial only to the productivity of joint ventures or affiliates, but not to that of domestic plants (Aitken

\footnotetext{
${ }^{7}$ In addition to these two main types of spillovers, there are competition and demonstration effects. Upon the market entry of foreign competitors equipped with more advanced technologies, local companies can be pushed to innovate and adopt more new technologies. However, in a strict sense, competition effects are not really spillovers, though they can stimulate firms to learn from their foreign competitors. For a further discussion on spillover channels, see Madariaga and Poncet (2007, p.841) and Cheung and Lin (2004, p. 26).
} 
and Harrison, 1999; Hu and Jefferson, 2002; Hale and Long, 2006) ${ }^{8}$. However other authors argue that FDI raises the long-term rate of productivity growth of domestic firms in the same industry (Liu 2008), and both SOEs and other locally owned enterprises can benefit from inward FDI (Buckley et al., 2007) 9 .

From the industrial perspective, researchers find a significant and positive relationship between FDI and Chinese industrial development (Liu and Buck, 2007; Liu et al., 2001; Liu, 2002; Liu and Wang, 2003; Gao, 2004) ${ }^{10}$. Hu and Jefferson (2002) point out that FDI has a strong positive impact on the productivity of the firms directly receiving FDI, but that the spillover effects from FDI in an industry are negative for its domestic firms. In contrast, Ito et al. (2012) argue that positive technology spillovers to domestic firms do exist in the same industry when the technological distance between domestic firms and foreign invested firms is not too large.

From the geographical perspective, some researchers indicate that FDI flows to adjacent locations should also be included in the analysis in addition to the direct FDI in one location. They believe that FDI is beneficial not only to the region that receives FDI, but also to its neighbouring regions (Madariage and Poncet, 2007). However, Girma and Wakelin conclude that while domestic firms do benefit positively from foreign firms in the same region and FDI spillovers occur within regions, there is no relationship or even a negative relationship between productivity in one region and FDI in other regions (Girma and Wakelin, $2002 \&$ 2007). Several studies on (direct) FDI spillovers in Chinese regions have been carried out in recent years (e.g. Cheung and Lin, 2004; Qi et al., 2009). However, there has not been much research on interregional (indirect) FDI spillovers between regions. This paper aims to address this gap.

\footnotetext{
${ }^{8}$ Aitken and Harrison (1999) and $\mathrm{Hu}$ and Jefferson (2002) are similar to each other in terms of methodology and findings, except that the former focuses only on the short-run effects in which FDI reduces the market shares of domestic firms. The latter study also includes the long-run effects, namely the domestic firms which survive the competition resulting from FDI, will be able to benefit from technology spillovers. Hale and Long (2006) find that FDI has a strong positive effect on private firms in China, while SOEs experience no or even negative impacts from FDI.

${ }^{9}$ They suggest that both types of firms (SOEs and other locally owned firms) benefit more in technology-intensive industries than in labour-intensive industries.

${ }^{10}$ The focuses of these researchers are different: Liu and Buck (2007) focus on high-tech industrial sectors, Liu et al. (2001) on Chinese electronics industry, while Liu (2002), Liu and Wang (2003) and Gao (2004) on general manufacturing/industrial sectors.
} 
Given the existing large disparities in productivity between regions in China, interregional spillovers are well recognized as a possible source of catch-up for poorer regions. This paper will bring both direct and indirect FDI spillovers, as well as interregional R\&D spillovers, into one framework. Examining both R\&D and FDI interregional spillover effect, we will explore in depth the dynamic contribution of technology spillovers to industrial growth in 29 Chinese regions ${ }^{11}$.

Technology spillovers (between firms, industries or regions) are affected by geographic distance, trade relationships and technological congruence. Some studies use trade weights or input-output relationships between industries as weights in estimating spillovers. We argue that these weights are more appropriate for estimating rent spillovers, and are less useful for pure knowledge spillovers. Hence no such trade-related weights will be used in our analysis. Besides trade-related weights, indicators of technological similarity can also be helpful in exploring the impact of spillovers (Jacob and Szirmai, 2007). However, given the difficulty in quantifying the technological congruence between regions, we have chosen to focus on geographic distance as our measure of closeness.

\subsection{Factors Influencing Technology Spillovers}

Four important factors influence technology spillovers: technology gaps, absorptive capacities, technological congruence and geographic distance.

Technology gaps. A technology gap provides a potential for lagging firms, regions or countries to benefit from knowledge spillovers from the units at the technological frontier, and thus to catch up rapidly (Gerschenkron, 1962; Griffith et al., 2004). At plant level spillovers have been analysed inter alia by Haskel et al. (2002), Girma and Wakelin (2001) and Girma et al. (2001).

At the national level, Fagerberg and Verspagen (2002) postulate a race between technological innovation within the leading countries which results in international divergence and international diffusion of technology to follower countries which results

${ }^{11}$ Chongqing and Sichuan count as one observation. 
in catch up (see also in Verspagen, 2001; Dosi et al., 1998; Szirmai, 2012). Using an equilibrium model, Glass and Saggi (1998) argue that a too large technology gap between host country and the country of origin limits the transfer of advanced technology via FDI. At the regional level, technology gaps are beneficial for the lagging regions. They allow them to leap to higher levels of economic and technological development in a short period of time (Girma, 2005). Though our statistical analysis will not focus specifically on lagging regions, it is clear that technology spillovers from regions with high levels of FDI and R\&D can profit from the insights of the catch up literature.

Absorptive capacity. In order to imitate or utilize the know-how spilling over from the leaders, the followers need certain capabilities (background knowledge, production experience, skilled personnel) to understand and apply new technologies. Abramovitz (1986) states that "a country's potential for rapid growth is strong not when it is backward without qualification, but rather when it is technologically backward but socially advanced" (Abramovitz, 1986, p. 388). Verspagen (1991) has also stressed the necessity of "learning capability" for a country in order to benefit from technological spillovers. He models learning capability as a combination of an "intrinsic" learning capability and the technological distance between the leader and the recipient. In addition to imitating innovations created by outside sources, absorptive capacity also provides an ability to learn from outside knowledge (Cohen and Levinthal, $1989 \&$ 1990). To have a positive spillover effect from more advanced regions, Girma (2005) argues that the receiver's absorptive ability should be higher than the threshold level.

Technological congruence. At the national level, technological congruence is another factor influencing the successful utilization of external sources of international technology (Abramovitz, 1986). It is easier for knowledge spillovers to take place if there is technological congruence between technology leaders and followers. Between the regions of a single country we expect to find more technological congruence than between different countries, due to similarities in culture, policies, and human resources than between countries. 
Geographic distance. Geographic distance is an important element in analyzing the effects of technological spillovers. Many empirical studies (Funke and Niebuhr, 2005; Orlando, 2004; Caniëls and Verspagen, 2001) show that the spillover effects decrease with distance. Through a spatial analysis of productivity effects of G-5 countries' R\&D spending in other OECD countries, Keller (2002) finds that "the distance at which the amount of spillovers is halved is about 1,200 kilometres" and he concludes that "technology is to a substantial degree local, not global, as the benefits from spillovers are declining with distance." López-Bazo et al. (2004) argue that the externalities across EU regions are locally bounded in the sense that they occur only within distances below 600 kilometres. Girma (2005) divides the UK into 14 regions and presents distance-weighted measures of foreign presence outside the region but within the same sector. Distance will be explicitly incorporated in our analysis.

\subsection{Spillover Models}

Various models have been used in the literature regarding technological externalities and spillovers. Four different categories of spillover models will be discussed below.

\section{Group 1: General technological spillovers}

A well-known approach to measure spillover effects is the augmented Cobb-Douglas production function, proposed by Griliches (1979):

$$
Y_{i t}=A_{i t} K_{i t}^{\alpha} L_{i t}^{\beta} R_{i t}^{\gamma} R_{i s t}^{\mu} e^{\varepsilon_{i t}}
$$

where $Y_{i t}$ stands for the value added in unit $i$ (firms, industries or regions) at time $t, K$, $L$ and $R$ are the physical capital input, labour input and technological knowledge input respectively ${ }^{12} . R_{i}$ is the direct science and technology input (normally represented by $\mathrm{R} \& \mathrm{D}$ expenditures or aggregated $\mathrm{R} \& \mathrm{D}$ stocks) in unit $i$, while $R_{\text {is }}$ indicates the indirect technological inputs (aggregated R\&D expenditures in other units) flowing from all these other units $s$ to unit $i$. The contribution of technological knowledge to the output of unit $i$ derives not only from its own R\&D expenditures, but also from the expenditures of other units. The coefficient $\gamma$ represents the direct contribution of

\footnotetext{
${ }^{12}$ Note that if Equation (1) is taken from the firm perspective, endogenous growth literature puts restrictions on the parameters such as $\alpha+\beta+\gamma=1$ and $R_{s t}$ can be viewed as an aggregate R\&D stock leading to knowledge spillovers to the individual firm. In case of an industry or regional perspective, $R_{i t}$ might already include intra-firm spillovers such that the abovementioned restriction on the parameters is not required (see e.g. Barro and Sala-i-Martin, 2004)
} 
$\mathrm{R} \& \mathrm{D}$, the coefficient $\mu$ the indirect contributions (spillovers) of R\&D. $\gamma$ and $\mu$ represent the partial elasticities of output with regard to direct $R \& D$ and indirect R\&D. $A_{i t}$ captures the level of total factor productivity (sometimes interpreted as the level of disembodied technology). Using logarithms, Equation (1) can be written as

$$
\ln \left(Y_{i t}\right)=a_{i t}+\alpha \ln \left(K_{i t}\right)+\beta \ln \left(L_{i t}\right)+r \ln \left(R_{i t}\right)+\mu \ln \left(R_{i s t}\right)+\varepsilon_{i t}
$$

This model has been widely adopted in measuring R\&D spillover effects (see Raut, 1995, p. 5; Los and Verspagen, 2000, p. 129; Coe and Helpman, 1995).

Most literature on inter-industry or international spillovers uses weights to aggregate external R\&D stocks, which are based on the correlations, similarities or degree of interaction between the destination and the origin of spillovers (Griliches, 1979; Aiello and Cardamone, 2005). In international spillover studies, trade volumes between two countries are used as weights (Coe and Helpman, 1995, p.860; Jacob and Szirmai, 2007). In inter-industry studies, use can be made of input-output tables. However, interregional input-output tables are scarce so, it is difficult to quantify such weights. Some researchers have simply used the unweighted aggregate R\&D expenditures of other regions (Raut, 1995; Wei and Liu, 2006). In this study we will use spatial distance between regions as weights, expressing the degree of regional closeness.

\section{Group 2: FDI spillovers}

The contribution of FDI to economic growth comes not only from its direct contribution to capital formation or employment creation, but also from its role as channel of international knowledge spillovers. ${ }^{13}$ Spillovers from FDI are among the technological spillovers which were discussed more generally in group 1. Most existing literature on FDI spillovers is also based on an extension of Equation (2). Given that the technology level of one region can be a result of both the direct technological influence from the foreign investment that has taken place in this region, and spillovers from FDI in other regions, two sources of spillover effects can be defined: $F D I_{i t}$ for direct FDI in region i, and $F D I_{i s t}$ for indirect FDI aggregated

\footnotetext{
${ }^{13}$ Technology spillovers are amongst the most important externalities associated with FDI. But there are other externalities such as competition effects and efficiency gains. We interpret the coefficients of FDI as technology spillovers, but there may be other effects involved as well.
} 
from other regions. If both R\&D and FDI are regarded as technology inputs, the equation for knowledge inputs will be

$$
\ln \left(Y_{i t}\right)=a_{i t}+\alpha \ln \left(K_{i t}\right)+\beta \ln \left(L_{i t}\right)+r \ln \left(R_{i t}\right)+\mu \ln \left(R_{i s t}\right)+\eta \ln \left(F D I_{i t}\right)+\lambda \ln \left(F D I_{i s t}\right)+\varepsilon_{i t}
$$

This formulation has been used by numerous authors in measuring FDI spillovers (Liu et al., 2001; Wei and Liu, 2006; Cheung and Lin, 2004).

\section{Group 3: Distinguishing between effects of foreign and domestic investment}

In estimating the direct effects of FDI on growth, one needs to distinguish between domestic investment and foreign investment. Usually, foreign investment is already included in the capital stock estimates. If one then simply adds FDI or FDI stocks to a model that already includes, this results in double counting. Balasubramanyam et al. (1996) separate the effects of FDI from domestic investment effects in their model as

$$
y=\alpha+\beta l+\gamma k+\psi f+\phi x
$$

where $y, l, k, f$, and $x$ are the growth rate of GDP, labour, domestic capital stock, foreign capital stock and exports respectively, and $\beta, \gamma, \psi$ and $\phi$ are their output elasticities. Being aware of, and having stressed the impact of spillovers and externalities from FDI, they show that FDI makes a more important contribution to growth than domestic investment, through comparing the coefficients of $\gamma$ and $\psi$. However, given that the two effects of FDI (international knowledge spillovers and capital investment) are included together in $\psi$, their work does not measure the spillover effect separately. But one might interpret a significant positive difference between $\psi$ and $\gamma$ as an indicator of the existence of international FDI spillover effects.

\section{Group 4: Accounting for the endogeneity of FDI}

As pointed out by Hale and Long (2011), most of the empirical studies on FDI spillovers in China suffer from an upward bias due to the endogeneity of FDI. Decisions on investment by foreign firms do not happen randomly. In order to maximize profits, foreign companies tend to select regions (or sectors) with higher potential growth capabilities and higher technology levels than other regions or sectors. In other words, FDI is more likely to take place in a region (or sector) with higher productivity and/or more rapid growth. Therefore the contributions of FDI will be exaggerated if part of regional or sectoral growth is misinterpreted as a FDI effect 
(Hale and Long, 2011; Hu and Jefferson, 2002). Ignoring the endogeneity of FDI results in an upward-bias in the estimates of international knowledge spillover effects.

To account for the endogeneity in firm-level analysis, Aitken and Harrison (1999), and $\mathrm{Hu}$ and Jefferson (2002) include an interaction term: firm-level FDI multiplied by industry-level FDI, which measures the impact of clustering of FDI (i.e. FDI goes to locations where there is already much FDI). A positive interaction term "indicates that more industry FDI makes firm-level FDI more productive, therefore giving reason to FDI clustering" (Hu and Jefferson, 2002, p.1068). In line with this approach, Buckley et al. (2002) also take into account the interactions between labour productivity and foreign investment. Taking a broader perspective than the model of $\mathrm{Hu}$ and Jefferson (2002), the foreign presence in Buckley et al. (2002) is assumed to be related to labour productivity, export intensity, market size, $R \& D$ intensity and labour quality in the studied industry. As stated by Aitken and Harrison (1999, p. 606), “..., if foreign investment gravitates towards more productive industries, then the observed correlation between the presence of foreign firms and the productivity of domestically owned firms will overstate the positive impact of foreign investment."

In our study, in order to capture the endogeneity of FDI in regions, we introduce an interaction term (between R\&D and FDI) measuring the presence of FDI in regions with high level local R\&D stock. A positive and statistically significant coefficient on the (R\&D and FDI) interaction term indicates that FDI contributes positively in a region with high a level of local R\&D stock.

\section{Data and methods}

To estimate the contribution of technological spillovers to the industrial output in regions, we need data for value added, capital input, employment, R\&D stock and foreign direct investment. This section describes the data we have collected and the methods used to analyse them.

\subsection{Data collection}

\section{Value added}


We collected value added time series by region from the China Statistical Yearbooks (CSY), and the China Industrial Economy Statistical Yearbooks (CIESY). Due to the inconsistencies in coverage and frequent changes of concepts in the published statistics, a series of adjustments has been made to create a consistent long-run time series (see Szirmai and Ren, 2007). Price indices of industrial products from the CSY (2003, p.313) are used to deflate the current price series of value added to constant 1990 prices.

\section{Capital input}

Published information on capital investment in Chinese statistics is not yet consistent with the SNA framework, which implies that such data cannot directly be used in productivity calculations. In recent years, considerable progress has been made in estimating capital stocks at the national level (e.g. Holz, 2006; $\mathrm{Wu}$ and $\mathrm{Xu}, 2002$; Chow, 1993; Huang et al., 2002). However, so far there has been little research on regional capital stocks. In this paper, we will use our own estimates of regional fixed capital stocks for 30 regions (Wang and Szirmai, 2012). These estimates are made for productive capital inputs rather than wealth capital stocks ${ }^{14}$. The preferred investment concept is Newly Increased Fixed Assets (NIFA). The perpetual inventory method has been adopted in constructing regional capital stocks from regional investment data. Three types of service lives are applied in the stock construction: 16 years for machinery and equipment, 30 years for non-residential fixed structures and 7 years for other investment (see more details on capital input estimation in Wang and Szirmai, 2012).

\section{Employment data}

Selecting employment data needs to be done with caution due to great inconsistencies of published data in Chinese yearbooks. For employment before 1993, we used staff and workers by sub-sector of industry (CIESY, 1993). For later years, we used staff and workers by detailed sub-sector from the labour statistics yearbooks CLSY, adjusting for the more limited concept of "in-post staff and workers". Also, post-1993

\footnotetext{
${ }^{14}$ Productive capital stock measures the productive capability or efficiency of capital and this concept is used in productivity analysis, while wealth capital stock reflects the market valuation of fixed assets, and it is used especially in business accounts.
} 
industrial employment figures are only published for urban areas. We made upward adjustments to these series to arrive at employment series for the total industrial sector (see also in Wang \& Szirmai, 2013). The new data is for "employment", so we don't have to adjust to include the non-on-post workers.

\section{R\&D Stock}

Data on science and technology are collected from the China Statistical Yearbook on Science and Technology (various issues). Intramural expenditure $R \& D$ by region is available from 1998 onward, but expenditure on science and technology (S\&T) activities $^{15}$, a reliable proxy for $\mathrm{R} \& \mathrm{D}$ expenditure, is available from 1990. S\&T expenditure covers $R \& D$ expenditure and also some other related expenses.

The S\&T expenditure generally (except in some earlier S\&T yearbooks) is the sum of four categories: independent research institutions, large \& medium-sized industrial enterprises, institutions of higher education, and others. The reason for using the sum of S\&T expenditure instead of that of mere industrial enterprises is that we intend to measure both intra- and inter-industry knowledge spillovers. Innovations used in industries can originate not only from laboratories of industrial enterprises, but also from independent research institutions, universities and other industries.

To estimate R\&D investment before 1998, we rely on S\&T expenditure and the average ratio of R\&D to S\&T between 1998 and 2002. Namely, we first calculate the five-year average ratio of R\&D to GDP for each region, and then apply this ratio to regional S\&T expenditure to get the estimated R\&D investment between 1990 and 1997. Using the same price deflator as value added, R\&D and S\&T data are also converted into constant 1990 prices.

R\&D stock is accumulated from each year with a given depreciation rate. Applying the perpetual inventory method, the R\&D capital stock of region $i$ at time $t\left(R D_{i t}\right)$ can be calculated by $R D_{i t}=R D_{i t-1}(1-\delta)+r d_{i t}$, where $\delta$ is the depreciation rate and $r d_{i t}$

\footnotetext{
${ }^{15}$ According to the China Statistical Yearbook on Science and Technology 2005 (p.436), the expenditure of science and technology activities refers to the actual total expenses spent in this particular unit on S\&T activities in the report period, including expenses on wages, research business, research management, fixed assets in non-basic construction, and other S\&D activities; not including the expenditure on productive activities, paying off loans or money transferred to other units.
} 
is the $\mathrm{R} \& \mathrm{D}$ expenditure of year $t$. The depreciation rate is assumed to be 15 per cent (Los and Verspagen, 2000; Griliches, 1990; Raut, 1995; Hall et al., 2010). The R\&D stock in the initial year can be estimated through dividing the R\&D expenditure in the initial year by the sum of growth rate of R\&D expenditure $(g)$ and the depreciation rate $(\delta$. i.e. $r d /(g+\delta)$ (Harberger, 1978, Coe and Helpman, 1995; Los and Verspagen, 2000). Given that the estimate of the initial R\&D stock greatly depends on the investment flow in the first year, an outlier year would bias the estimates. Due to the considerable volatility of the growth rates of $R \& D$ expenditure in the early years, we apply the growth rates of the entire period, i.e., average of 1990-2005. Moreover, we calculate the initial stock 16 times, using the $R \& D$ expenditure in all years, and then take the average of these $R \& D$ stocks as our estimate of the initial stock. The generalized equation is as follows:

$$
\frac{r d_{t} *(1+g)^{(1-t)}}{g+\delta} \mid t=1,2, \ldots 16
$$

Where $\mathrm{g}$ is the average growth rate of S\&T expenditure during 1990-2005; R\&D investment flow $r d$ was taken in the whole period $(1990,1991 \ldots 2005)$.

Interregional $R \& D$ spillovers are calculated by the distance weighted sum of $R \& D$ stock in other regions, see Equation (7) and (8) below.

\section{Foreign Direct Investment}

To address the problem of double counting in capital investment, we use regional FDI intensity, i.e. the regional ratio of FDI to TIFA (total investment in fixed assets), rather than regional FDI itself. If regional FDI intensity has a significant impact on regional growth, we interpret this as the effect of international knowledge spillovers to the region, over and above the effects of FDI as incorporated in the regional capital stock

Data are collected from China Statistical Yearbook on Investment in Fixed Assets, 1950-1995, Statistics on Investment in Fixed Assets in China, 1995-2000 and China Statistical Yearbook (various issues) ${ }^{16}$. Capital input and labour input of foreign

\footnotetext{
${ }^{16}$ The published FDI data in Chinese yearbooks are in US dollars (at current prices). Before calculating the ratios, we adjusted FDI to Chinese yuan (at current prices), and further to the same constant price as total investment in fixed assets.
} 
companies are already included in the variables of capital (K) and labour (L), so these should not be double counted by adding extra variables for them. Indirect FDI spillovers received from other regions are calculated in the same way as $R \& D$ spillovers, see also Equation (7) and (8).

\subsection{Methodology}

The aim of this paper is to examine interregional technology spillovers. To do so, we distinguish the effects of direct regional $R \& D$ inputs, $R \& D$ spillovers from other regions, international knowledge spillovers embodied in direct regional FDI, and interregional spillovers from FDI in other regions. In the present study, the units of analysis are 29 Chinese regions ${ }^{17}$.

The spillover model used in this paper is derived from Aitken and Harrison (1999) and $\mathrm{Hu}$ and Jefferson (2002). As explained in section 2, the merit of the models of Aitken and Harrison (1999) and Hu and Jefferson (2002) is to tackle the endogeneity issue by including a FDI clustering term. Elaborating on their methodology, we also include regional absorptive capacity as embodied in the regional R\&D level in explaining FDI spillover effects. Considering that most foreign companies have more advanced equipment and technology than domestic companies, they will prefer to invest in regions that are most capable of cooperating with them. Thus, we distinguish two endogenous effects on FDI: one is due to the clustering effect of FDI (FDI flows to regions that have higher levels of FDI); the other is due to the technological capability of this region (FDI flows to regions with higher levels of domestic R\&D). Hence, our extended model (Equation 5) involves not only the interaction term between FDI and the aggregate FDI from other regions, but also the interaction term between FDI and the regional technology level. In order to capture technological change over time, we also include a technology parameter, i.e. $A_{t}=a_{0} \cdot e^{a \cdot t_{1}}$. Taking logarithms, we get $\ln \left(A_{t}\right)=\ln a_{0}+a_{1} \cdot t$. Therefore, we have the following model:

\footnotetext{
${ }^{17}$ Of the 31 provincial-level regions in mainland of China, our paper covers 30 regions. Tibet is not
} included in our analysis due to lack of data. Chongqing and Sichuan are combined as one observation. 


$$
\begin{aligned}
& \ln \left(Y_{i t}\right)=a_{0}+a_{1} \cdot t+\alpha \ln \left(K_{i t}\right)+\beta \ln \left(L_{i t}\right)+\gamma_{1} \ln \left(R D e_{i t}\right)+\gamma_{2} \ln \left(R D S e_{i t}\right)+ \\
& \gamma_{3} \ln \left(F D I_{i t}\right)+\gamma_{4} \ln \left(F D I S_{i t}\right)+\gamma_{5} \ln \left(R D e_{i t}\right) * \ln \left(F D I_{i t}\right)+r_{6} \ln \left(F D I_{i t}\right) * \ln \left(F D I S_{i t}\right)+(6)^{18} \\
& \gamma_{7} \ln \left(R D e_{i t}\right) * \ln \left(F D I S_{i t}\right)+\varepsilon_{i t}
\end{aligned}
$$

Where

$Y_{i t}$--- the industrial value-added of region $i$ at time $\mathrm{t}$;

$K_{i t}$--- the industrial capital stock of region $i$ at time t;

$L_{i t}$--- number of persons engaged in industry in region $i$ at time $t$;

$R D e_{i t}{ }^{---}$levels of $\mathrm{R} \& \mathrm{D}$ stock in region $i$ at time $\mathrm{t}$;

$F D I_{i t}$--- FDI share in total investment (i.e. FDI/TIFA ratio) in region $i$ at time t; the coefficient of this term measures international spillovers;

$R D S e_{i t}$--- aggregated R\&D stock levels from other regions ${ }^{19}$; the coefficient of this terms measures interregional spillovers;

FDIS $_{i t}$--- aggregated FDI levels from other regions $^{20}$; the coefficient of this term measures international spillovers coming via other regions.

$\ln \left(R D e_{i t}\right) * \ln \left(F D I_{i t}\right)$ - interactions between local R\&D stock and international FDI spillovers.

$\ln \left(F D I_{i t}\right) * \ln \left(F D I S_{i t}\right)$ - interactions between FDI and FDI in neighbouring regions. $\ln \left(R D e_{i t}\right) * \ln \left(F D I S_{i t}\right)$ - interactions between local R\&D stock and indirect FDI spillovers.

In Equation (5) the interaction terms, $\ln \left(R D e_{i t}\right) * \ln \left(F D I_{i t}\right), \ln \left(F D I_{i t}\right) * \ln \left(F D I S_{i t}\right)$ $\ln \left(R D e_{i t}\right) * \ln \left(F D I S_{i t}\right)$ are introduced into the regressions one by one. In the estimations we will use one year lag for all the technology related terms and a half year lag for capital inputs.

The closer two regions are to each other, the greater the possibilities for communication and business and labour flows. Hence there will be more

\footnotetext{
${ }^{18}$ Representing the logged variable with lower case characters, Equation (6) can be also written as $y_{i t}=a_{0}+a_{1} \cdot t+\alpha k_{i t}+\beta l_{i t}+\gamma_{1} r d e_{i t}+\gamma_{2} r d s e_{i t}+\gamma_{3} f d i_{i t}+\gamma_{4} f d i_{i t}+\gamma_{5} r d e_{i t} * f d i_{i t}+$ $r_{6} f d i_{i t} *$ fdis $_{i t}+\gamma_{7}$ rde $_{i t} *$ fdis $_{i t}+\varepsilon_{i t}$

${ }^{19}$ Geographic distance is used as weight in aggregating the R\&D stock from outside regions.

${ }^{20}$ Geographic distance is used as weight in aggregating the FDI level from outside regions.
} 
opportunities for knowledge spillovers. In this paper, geographic distance is used as weight in aggregating spillovers from outside regions, with regard to both $R \& D$ and FDI, as follows:

$$
\begin{aligned}
& R D S_{i t}=\sum_{j \neq i} w_{i j} R D_{j t} \\
& \text { FDIS }_{i t}=\sum_{j \neq i} w_{i j} F D I_{j t}
\end{aligned}
$$

Equation (6) measures the external R\&D stock $i$ as equal to the distance weighted sum of all other regions' R\&D stock. Likewise, FDI from outside regions received by region $i$ equals the distance weighted sum of all other regions' FDI. $w_{i j}$ is the standardized spatial weight between region $i$ and $j$. Suppose the geographical distance between region $i$ and $j$ is $d_{i j}$, the spatial weight matrix (see also Ertur et al., 2006) can then be expressed as follows:

$$
\begin{aligned}
& w_{i j}^{*}=0 \text { if } i=j \\
& w_{i j}^{*}=1 / d_{i j}^{2} \text { if } d_{i j} \leq \text { cutoff } \\
& w_{i j}^{*}=0 \text { if } d_{i j}>\text { cutoff }
\end{aligned}
$$

in which the distance weight is taken as the inverse of squared distance between region $i$ and $j^{21}$. To standardize it, we can use $w_{i j}=w_{i j}^{*} / \sum_{j} w_{i j}^{*}$. Thus the sum of each row in the matrix is equal to 1 .The cut-off parameter has been chosen differently by different researchers (see Baumont et al., 2000, for taking different distance parameters as well as working without cut-off). We argue that a cut-off distance should be used given that a region is less likely to be influenced by very distant regions. We take 1520 kilometres as the cut-off distance ${ }^{22}$. This guarantees that each region in China has at least one region with which it interacts.

Since we believe that investments in $R \& D$ and foreign direct investment have a lagged impact on the level of technology and to avoid the endogeneity problem of these variables a one year lag has been applied to $R \& D$, R\&D spillovers, FDI, indirect

\footnotetext{
${ }^{21}$ Distance of provinces is measured by their capital cities, considering that a capital city is usually the central business and technology center of each province.

${ }^{22}$ Madariaga and Poncet (2007) use the same method by taking a distance at $1624 \mathrm{~km}$, but our data on regional distance are slightly different from what they collected.
} 
FDI spillovers and interaction terms. For the capital stock we used a half year lag which is commonly used in the literature.

\section{Empirical Results}

\subsection{Regional distribution of $R \& D$ and FDI}

It is well known that Chinese $R \& D$ and FDI are very unequally distributed across regions. Before embarking on an econometric analysis of regional R\&D and FDI spillovers, we start with description of trends on R\&D and FDI and their distribution across regions.

R\&D expenditures at constant 1990 prices increased from 12.5 billion Yuan in 1990 to 144.3 billion Yuan in 2007. Between 1990 and 1998 the expenditures grew at 9 per cent per year. After 1998, there was an explosive growth of R\&D expenditures. They increased by an annual rate of 21.6 per cent between 1998 and 2007. In 1998, Beijing accounted for 21 per cent of all S\&T expenditure, followed by Shanghai with 9.3 per cent, Guangdong with 8.4 per cent, Jiangsu with 7.4 per cent and Sichuan with 7.3 per cent. Six regions (the previous five plus Shaanxi) accounted for sixty percent of all S\&T expenditures in China. By 2007, the share of the top six regions still remains about 60 per cent, but there have been some interesting shifts among the leading regions. Beijing (13.6 per cent), Shanghai (8.3 per cent), Sichuan and Shaanxi have become less prominent, while regions such as Jiangsu (11.6 per cent), Shandong (8.4 per cent), Guangdong (10.9 per cent) and Zhejiang (7.6 per cent) have greatly increased their shares in Chinese R\&D.

It is well-known that there have been huge increases in inward FDI to China since 1990. China started at very low levels and then became one of the most important destinations of FDI. It is interesting to note that the aggregate trends for FDI are very different from those for R\&D. Between 1990 and 1998 there was a spectacular growth of FDI (at 1990 constant prices) from 15.5 billion Yuan to 192 billion Yuan. The annual growth rate was 37 per cent per year. After 1998, just when R\&D expenditures started to grow very rapidly, the growth rate of FDI slowed down. FDI reached a level of 227.8 billion Yuan by 2005. The average growth rate between 1998 and 2005 was 
only 2.5 per cent per year. So there is an interesting shift from FDI driven growth to domestic R\&D driven growth. After 1998, not only does domestic R\&D increase rapidly, but also domestic capital investment in general (see UNIDO, 2012).

As regards destination FDI was much more concentrated than R\&D. In 1990 Guangdong alone accounted for 45 per cent of all FDI inflows. Five regions (Guangdong, Liaoning, Shanghai, Fujian and Beijing accounted for 76 per cent of all FDI). By 2005, five regions still accounted for over 70 per cent of FDI (Shanghai, Shandong, Guangdong and Zhejiang), but the share of Guangdong had declined to 20.5 per cent, followed by Jiangsu with 15.8 per cent.

Instead of focusing only on regional shares in R\&D and FDI, it is also interesting to chart the regional distribution of $R \& D$ and FDI intensity. Both R\&D and FDI intensities are calculated as ratios to regional GDP. The intensity is taken as the average of a 5 year period, which reduces the influence of outlier years. Two time periods are distinguished to highlight changes over time: 1990-94 and, and 2001-05. Darker shades represent higher intensities.

In the earlier period R\&D intensity is highest in four coastal regions (Beijing, Tianjin, Liaoning and Shanghai) and four regions located in the middle of China (Gansu, Shaanxi, Sichuan and Chongqing). In the period 2001-5, two more coastal regions (Guangdong and Jiangsu) have joined the high R\&D intensity group, while three middle regions have dropped out. Though $R \& D$ intensity is still fairly well spread over regions, it is becoming more concentrated in the coastal regions. The intensity of foreign direct investment presents a clear coastal focus in both periods.

Figure 1: Regional distribution of R\&D intensity (ratio of R\&D to GDP)
a) $1990-94$ (5 year average)
b) 2001-05 (5 year average)
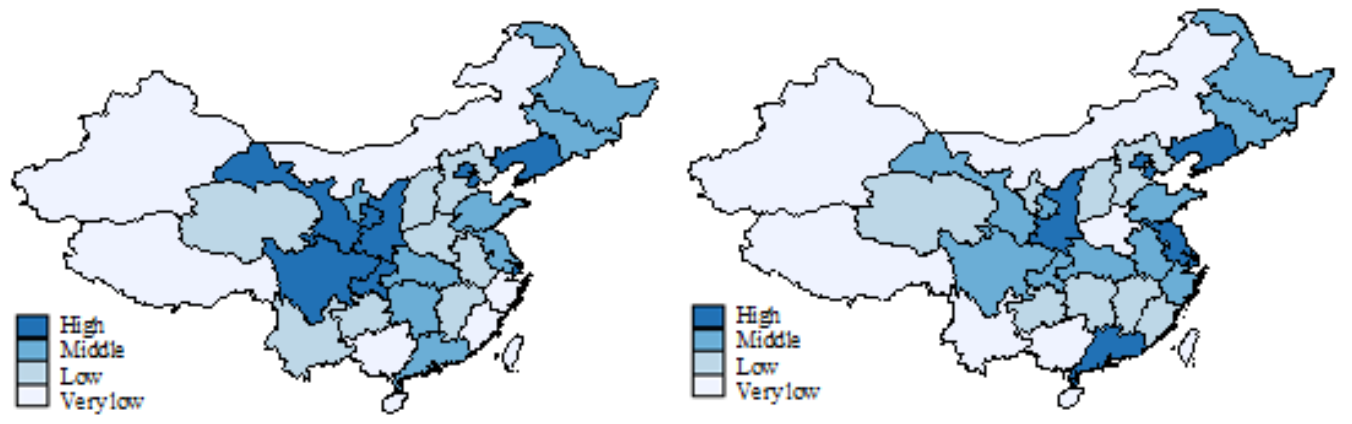
Source: Authors' own calculation. Data are collected from China Statistical Yearbook on Science \& Technology (various issues) and China Statistical Yearbook (various issues).

Note: 1) R\&D intensity is the ratio of R\&D expenditure to GDP. 2) Tibet is not included due to lack of data. 
Figure 2: Regional distribution of FDI intensity (ratio of FDI to GDP)

a) $1990-94$ (5 year average)

b) 2001-05 (5 year average)
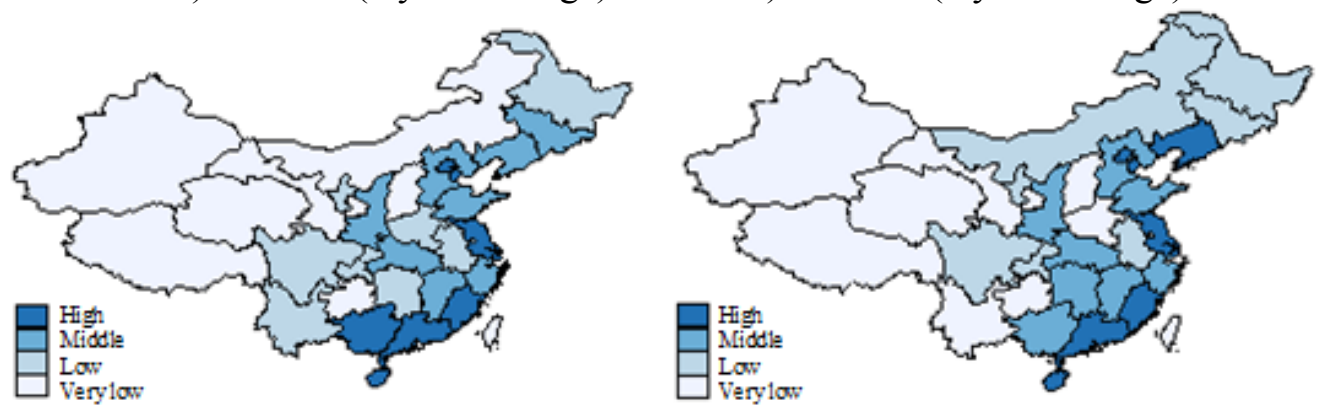

Source: Authors' own calculation. . Data are collected from China Statistical Yearbook on Investment in Fixed Assets, 1950-1995, Statistics on Investment in Fixed Assets in China, 1995-2000 and China Statistical Yearbook (various issues).

Note: 1) FDI intensity is the ratio of FDI to GDP. 2) Tibet is not included due to lack of data.

Overall, the intensity maps depict different patterns in the investment distribution of R\&D and FDI. High FDI-intensity occurs mainly in coastal regions (in both earlier and later stages), while in the earlier period high R\&D-intensity can be also seen in central regions of China. With regard to $R \& D$ intensity, we do observe a shift from middle to coast between the two periods.

\subsection{Econometric Analysis}

Our empirical analysis covers effects of technological spillovers on output in 29 Chinese regions ${ }^{23}$ during 1990-2005. In the following tables, the coefficient of $r d e_{t-1}$ refers to the logged value of the direct effect of $R \& D$ inputs, measured by the $R \& D$ stock with a one year lag. The coefficient of $f d i_{t-1}$ refers to international FDI spillovers, measured by the ratio of foreign direct investment to total investment in fixed assets (TIFA), with a one year lag. The coefficients of $r d s e_{t-1}$ and $f d i s_{t-1}$ represent the logged value of interregional spillover effects of R\&D and FDI from other regions with one year lag. $r d e_{t-1} * f d i_{t-1}$ is the interaction term between local R\&D stock and FDI, $f d i_{t-1} * f d i s_{t-1}$ is the interaction term between direct FDI spillovers and indirect (interregional) FDI spillovers, and $r d e_{t-1} * f d i s_{t-1}$ is the

\footnotetext{
${ }^{23}$ Chongqing is included in Sichuan. Tibet is excluded because of its lack of FDI data.
} 
interaction term between local R\&D stock and indirect (interregional) FDI spillovers $^{24}$. We take also natural log for the value added, capital and labour.

It is very likely that the level of technology differs between regions and since we are estimating a production function in $(\log )$ levels, we should employ a fixed effect panel model, or region dummies, to catch these differences. A formal Hausman test indeed indicates a strong preference of using the fixed effect model above the (more restrictive) random effects model and the tables below provide panel fixed effects results. First estimates and inspection of the results showed clear breaks in the residuals and we therefore added break years in our model to allow for structural breaks in the coefficients. While selecting the break year, we include flexible breakpoints in our regressions, which means that the Chow test is carried out for all possible break years between 1995 and 2002 by adding slope-shift dummies for all variables. The year with the most significant $F$ test is chosen. This is done in all listed variants of the model. In almost all cases the most significant break year turns out to be 1998 and we used a break in 1998 in all our specifications.

In addition to adding a time trend to capture improvements in technology exogenous to the model, we also experimented by including year dummies leading to a so called two-way fixed effect panel model. If coefficients that are significant in the time trend specification remain significant in the year dummy version of the model, this is a confirmation that the correlation as found in the model that includes a time trend is not due to a common missing other factor. If the coefficients in the year dummy version of the model are not significant, while they are significant in the time trend specification, this can indeed be due to a missing common factor, but it could also be caused by less variance between regions as the year dummies capture all differences. Therefore, significant results in the year dummy version would confirm the relevance of that particular variable, but insignificant results do not necessarily prove the opposite $^{25}$. The regression results of the time trend models are presented in the following tables while models with year dummies are reproduced in the Annex. ${ }^{26}$.

\footnotetext{
${ }^{24}$ All the interaction terms are also presented in the estimated in the logarithmic value with one year lag.

${ }^{25}$ The results from year dummy models are consistent with those from time trend models. The only difference is that the coefficients of $R \& D$ spillovers become insignificant when time dummies are incorporated into the models. The reason is that time dummies capture a significant part of the
} 
Table 1 presents four year-break models. Specification 1 includes $R \& D$ and $R \& D$ spillovers (Col. 1); Specification 2 examines international direct FDI spillovers and interregional indirect FDI spillovers (Col.2); Specification 3 reports R\&D, R\&D spillovers and two types of FDI spillovers (Col.3); Specification 4 includes all R\&D and FDI variables as well an interaction term between local R\&D stock and FDI effect (Col.4). All results are based on panel fixed effects estimates using robust sandwich estimator of the variance and HAC covariance estimation (Newey-West). Our preferred specifications are those of column 3 and 4, though we also refer to the other specifications in the text.

Table 2 takes column of Table 1 as point of departure and provides the results of three models which further examine the effects of introducing interaction terms ${ }^{27}$. These regressions exclude non-significant variables. For instance, Col. 4 in Table 1 is different from Col. 1 in Table 2. The former includes all variables, while the latter excludes the FDI variable which is not significant in Table 1. For each variable in both tables, there are two coefficients for different periods, one before the break year $(\mathrm{t}<1998)$ and one after the break year $(\mathrm{t}>=1998)$.

\footnotetext{
contribution of interregional R\&D spillovers to the industrial value added, hence R\&D spillovers seem less important in those time-dummy models. This indicates that interregional R\&D spillover effect between regions over time is more than between time over region. Since R\&D spillovers are based on distance weighted averages of regional $R \& D$ stocks it is indeed somewhat to be expected that regional differences are less pronounced. Another minor difference is that for a couple of cases, the R\&D effect after 1998 becomes insignificant in the year dummy models, mainly due to the fact that the year dummies capture most changes over years.

${ }^{26}$ Year dummies are not reported in the tables.

${ }^{27}$ Interaction term between R\&D and R\&D spillovers was also tested, but not included in the results because of its non-significant result.
} 
Table 1: Determinants of Regional Gross Domestic Product, 1990-2005 Estimates of R\&D, R\&D spillovers and FDI spillovers

\begin{tabular}{|c|c|c|c|c|}
\hline & $\begin{array}{c}\text { R\&D and R\&D spillovers } \\
\text { (1) }\end{array}$ & $\begin{array}{l}\text { FDI spillovers } \\
\text { (2) } \\
\end{array}$ & $\begin{array}{l}\text { All } \\
\text { (3) }\end{array}$ & $\begin{array}{l}\text { all with interaction term } \\
\text { rde*fdi } \\
\text { (4) }\end{array}$ \\
\hline$k_{t-1 / 2}, \mathrm{t}<1998$ & $\begin{array}{l}0.385^{* * *} \\
(\odot .0839)\end{array}$ & $\begin{array}{l}0.408^{* * *} \\
(0.0822)\end{array}$ & $\begin{array}{l}0.411^{* * *} \\
(0.0921)\end{array}$ & $\begin{array}{l}0.411 * * * \\
(0.0922)\end{array}$ \\
\hline$k_{t-1 / 2}, t>=1998$ & $\begin{array}{l}0.698 * * * \\
(0.0946)\end{array}$ & $\begin{array}{l}0.610 * * * \\
(0.0869)\end{array}$ & $\begin{array}{c}0.708^{* * *} \\
(0.111)\end{array}$ & $\begin{array}{c}0.707 * * * \\
(0.112)\end{array}$ \\
\hline$l_{t}, \mathrm{t}<1998$ & $\begin{array}{l}0.642 * * * \\
(0.0552)\end{array}$ & $\begin{array}{l}0.678 * * * \\
(0.0481)\end{array}$ & $\begin{array}{l}0.626 * * * \\
(0.0574)\end{array}$ & $\begin{array}{l}0.632 * * * \\
(0.0574)\end{array}$ \\
\hline$l_{t}, \mathrm{t}>=1998$ & $\begin{array}{l}0.391 * * * \\
(0.0495)\end{array}$ & $\begin{array}{l}0.496 * * * \\
(0.0461)\end{array}$ & $\begin{array}{l}0.376 * * * \\
(0.0512)\end{array}$ & $\begin{array}{l}0.383^{* * *} \\
(\odot .0521)\end{array}$ \\
\hline$r d e_{t-1}, \mathrm{t}<1998$ & $\begin{array}{l}0.115^{* *} \\
(0.0515)\end{array}$ & & $\begin{array}{l}0.141 * * \\
(0.0569)\end{array}$ & $\begin{array}{l}0.139 * * \\
(0.056)\end{array}$ \\
\hline$r d e_{t-1}, \mathrm{t}>=1998$ & $\begin{array}{l}0.0996^{*} \\
(0.0567)\end{array}$ & & $\begin{array}{l}0.134^{* *} \\
(0.0613)\end{array}$ & $\begin{array}{l}0.140 * * \\
(0.0623)\end{array}$ \\
\hline$r d s e_{t-1}, \mathrm{t}<1998$ & $\begin{array}{c}0.0765 \\
(0.0709)\end{array}$ & & $\begin{array}{c}0.108 \\
(0.0826)\end{array}$ & $\begin{array}{c}0.105 \\
(0.0838)\end{array}$ \\
\hline$r d s e_{t-1}, t>=1998$ & $\begin{array}{l}0.140^{* *} \\
(0.0678)\end{array}$ & & $\begin{array}{l}0.187^{* *} \\
(0.0787)\end{array}$ & $\begin{array}{l}0.182 * * \\
(0.0805)\end{array}$ \\
\hline$f d i_{t-1}, \mathrm{t}<1998$ & & $\begin{array}{c}0.00147 \\
(0.00147)\end{array}$ & $\begin{array}{c}0.00118 \\
(0.0013)\end{array}$ & $\begin{array}{l}0.000597 \\
(0.0048)\end{array}$ \\
\hline$f d i_{t-1}, \mathrm{t}>=1998$ & & $\begin{array}{c}0.00591 * * * \\
(0.00198) \\
\end{array}$ & $\begin{array}{c}0.00410 * * \\
(0.0018) \\
\end{array}$ & $\begin{array}{c}0.0109 \\
(\odot .0079) \\
\end{array}$ \\
\hline $\begin{array}{l}\text { fdis }_{t-1}, \mathrm{t}<1998 \\
\text { fdis }_{t-1}, \mathrm{t}>=1998\end{array}$ & & $\begin{array}{c}0.000864 \\
(0.00276) \\
-0.00084 \\
(0.00373)\end{array}$ & $\begin{array}{c}-0.00199 \\
(0.00313) \\
-0.0136 * * * \\
(0.00405)\end{array}$ & $\begin{array}{c}-0.00205 \\
(0.00314) \\
-0.0143^{* * *} \\
(0.00418)\end{array}$ \\
\hline$r d e_{t-1} * f d i_{t-1}, \mathrm{t}<1998$ & & & & $\begin{array}{l}0.0000979 \\
(0.000666)\end{array}$ \\
\hline$r d e_{t-1} * f d i_{t-1}, \mathrm{t}>=1998$ & & & & $\begin{array}{l}-0.000829 \\
(0.000953) \\
\end{array}$ \\
\hline$t, \mathrm{t}<1998$ & $\begin{array}{c}0.0076 \\
(0.0123) \\
\end{array}$ & $\begin{array}{l}0.0268^{* * *} \\
(0.00781)\end{array}$ & $\begin{array}{c}-0.000951 \\
(0.0126) \\
\end{array}$ & $\begin{array}{c}-0.000568 \\
(0.0126) \\
\end{array}$ \\
\hline$t, \mathrm{t}>=1998$ & $\begin{array}{c}0.0763 * * * \\
(0.0134)\end{array}$ & $\begin{array}{c}0.125 * * * \\
(0.00898)\end{array}$ & $\begin{array}{c}0.0575 * * * \\
(\odot .0184)\end{array}$ & $\begin{array}{c}0.0582 * * * \\
(0.0184)\end{array}$ \\
\hline Prob $>F$ & 0.0000 & 0.0000 & 0.0000 & 0.0000 \\
\hline Centered R2 & 0.9401 & 0.9364 & 0.9420 & 0.9421 \\
\hline Uncentered R2 & 0.9401 & 0.9364 & 0.9420 & 0.9421 \\
\hline N & 464 & 464 & 464 & 464 \\
\hline
\end{tabular}

Note: Dependent variable is industrial value added. Fixed effect models, Robust standard errors are in parentheses. $* * *$ at 1 per cent significance level; $* *$ at 5 per cent significance level; and $*$ at 10 per cent significance level. 
Table 2: Determinants of Regional Gross Domestic Product, 1990-2005 Estimates of R\&D, R\&D spillovers and FDI spillovers with interaction terms

\begin{tabular}{|c|c|c|c|}
\hline & $\begin{array}{l}\text { interaction term } r d e^{*} f d i \\
\text { (1) }\end{array}$ & $\begin{array}{l}\text { interaction term } f d{ }^{*} \text { fdis } \\
\text { (2) }\end{array}$ & $\begin{array}{l}\text { interaction term rde }{ }^{*} \text { fdis } \\
\text { (3) }\end{array}$ \\
\hline$k_{t-1 / 2}, \mathrm{t}<1998$ & $\begin{array}{l}0.407^{* * *} \\
(0.0931)\end{array}$ & $\begin{array}{l}0.424^{* * *} \\
(0.0893)\end{array}$ & $\begin{array}{l}0.415^{* * *} \\
(0.0894)\end{array}$ \\
\hline$k_{t-1 / 2}, t>=1998$ & $\begin{array}{l}0.710 * * * \\
(0.111)\end{array}$ & $\begin{array}{l}0.713 * * * \\
(0.102)\end{array}$ & $\begin{array}{l}0.739 * * * \\
(0.101)\end{array}$ \\
\hline$l_{t}, \mathrm{t}<1998$ & $\begin{array}{l}0.627^{* * *} \\
(0.0577)\end{array}$ & $\begin{array}{l}0.607^{* * *} \\
(0.0546)\end{array}$ & $\begin{array}{l}0.650^{* * *} \\
(0.0552)\end{array}$ \\
\hline$l_{t}, \mathrm{t}>=1998$ & $\begin{array}{l}0.373 * * * \\
(0.0513)\end{array}$ & $\begin{array}{l}0.366 * * * \\
(0.0487)\end{array}$ & $\begin{array}{l}0.376 * * * \\
(\odot .0493)\end{array}$ \\
\hline$r d e_{t-1}, \mathrm{t}<1998$ & $\begin{array}{l}0.144^{* *} \\
(0.0571)\end{array}$ & $\begin{array}{l}0.144^{* * *} \\
(0.0513)\end{array}$ & $\begin{array}{l}0.146 * * * \\
(0.0507)\end{array}$ \\
\hline$r d e_{t-1}, \mathrm{t}>=1998$ & $\begin{array}{c}0.133^{* *} \\
(0.0621)\end{array}$ & $\begin{array}{c}0.138 \text { * * } \\
(0.0564)\end{array}$ & $\begin{array}{c}0.153 * * * \\
(0.057)\end{array}$ \\
\hline $\begin{array}{l}\text { rdse }_{t-1}, \mathrm{t}<1998 \\
\text { rdse }_{t-1}, \mathrm{t}>=1998\end{array}$ & $\begin{array}{c}0.106 \\
(0.0841) \\
0.187^{* *} \\
(0.0802) \\
\end{array}$ & $\begin{array}{l}0.127^{*} \\
(0.0753) \\
0.210^{* * *} \\
(0.0726) \\
\end{array}$ & $\begin{array}{c}0.115 \\
(0.0755) \\
0.197^{* * *} \\
(0.0728) \\
\end{array}$ \\
\hline $\begin{array}{l}\text { fdis }_{t-1}, \mathrm{t}<1998 \\
\text { fdis }_{t-1}, \mathrm{t}>=1998\end{array}$ & $\begin{array}{c}-0.00199 \\
(0.00311) \\
-0.0131 * * * \\
(0.00404)\end{array}$ & $\begin{array}{c}-0.000376 \\
(0.00332) \\
-0.0160 * * * \\
(0.00486)\end{array}$ & \\
\hline $\begin{array}{l}r d e_{t-1} * f d i_{t-1}, t<1998 \\
r d e_{t-1} * f d i_{t-1}\end{array}$ & $\begin{array}{c}0.000158 \\
(0.000178) \\
0.000439 * * \\
(0.000221)\end{array}$ & & \\
\hline $\begin{array}{l}f d i_{t-1} * \text { fdis }_{t-1}, \mathrm{t}<1998 \\
\text { fdi }_{t-1} * \text { fdis }_{t-1}, \mathrm{t}>=1998\end{array}$ & & $\begin{array}{c}-0.0000655 \\
(0.0000899) \\
0.000285^{*} \\
(0.000148)\end{array}$ & \\
\hline$r d e_{t-1} *$ fdis $_{t-1}, \mathrm{t}<1998$ & & & $\begin{array}{c}-0.000278 \\
(0.000313)\end{array}$ \\
\hline $\operatorname{rde}_{t-1} *$ fdis $_{t-1}, \mathrm{t}>=1998$ & & & $\begin{array}{l}-0.00147 * * * \\
(0.000478)\end{array}$ \\
\hline$t, \mathrm{t}<1998$ & $\begin{array}{l}-0000852 \\
(0.0128)\end{array}$ & $\begin{array}{l}-\odot .00377 \\
(\odot .0121)\end{array}$ & $\begin{array}{l}-0.000609 \\
(0.0122)\end{array}$ \\
\hline$t, \mathrm{t}>=1998$ & $\begin{array}{c}0.0567^{* * *} \\
(0.0185)\end{array}$ & $\begin{array}{l}\odot .0519 * * * \\
(\odot .017 \odot)\end{array}$ & $\begin{array}{c}\odot .0502 * * * \\
(0.0169)\end{array}$ \\
\hline Prob $>F$ & 0.0000 & 0.0000 & 0.0000 \\
\hline Centered R2 & 0.9419 & 0.9421 & 0.9415 \\
\hline Uncentered R2 & 0.9419 & 0.9421 & 0.9415 \\
\hline$N$ & 464 & 464 & 464 \\
\hline
\end{tabular}

Note: Dependent variable is industrial value added. Fixed effect models, Robust standard errors are in parentheses. $* * *$ at 1 per cent significance level; ** at 5 per cent significance level; and * at 10 per cent significance level. 


\section{Importance of the year-break}

The year break coefficients for capital and employment are all highly significant $(p<0.01)$, and the year break coefficients for other variables are also usually significant in both Table 1 and 2. In particular, in all type of models, there is a clear shift in the between capital and labour, i.e. the coefficient of capital was around 0.4 before the break year 1998 and around 0.6 or 0.7 afterwards; the coefficient of labour changed from 0.6 before the break to 0.4 after the break. All of this indicates that adding the year-break is of considerable importance. The changes of elasticities of capital and labour indicate that the industry in China changed from a labour-driven growth to a capital-driven growth.

\section{Contribution of $R \& D$ stock and $R \& D$ spillovers}

The coefficients of the $R \& D$ stock are statistically significant in almost all specifications in Table 1. However the contribution of R\&D decreases slightly after the year break 1998, in particular in the regression for R\&D and R\&D spillovers (Col. 1 of Table 1). This result is in line with the earlier findings of Hu and Jefferson (2004) and Jiang et al. (2010) who find that returns to R\&D and its productivity have declined over years.

Regarding the interregional $R \& D$ spillovers, it is interesting that $R \& D$ spillovers contribute significantly and positively to regional industrial value added only in the period after 1998 (see Table 1 and 2). This indicates that regions did not yet receive significant spillover effects from the R\&D invested by their neighbouring regions until 1998. The coefficients of lagged interregional R\&D spillovers after $1998\left(r_{s d s}{ }_{t-1}\right.$, $t>=1998)$ are positive and statistically significant in all regressions in Table 1 and 2.

\section{Direct and indirect foreign technological spillovers}

With regard to the contribution of FDI, we find a clear break. The direct international FDI spillover is positive and significant in the models which do not include interaction term. But this effect exists only after 1998. The evidence indicates that the contribution difference between before- and after- 1998 is closely related to the regional R\&D changes. As stated in section 4.1, the R\&D expenditures grew at 9 per cent per year between 1990 and 1998, but after 1998, there is a much faster and 
explosive growth, R\&D expenditures increasing by an annual rate of 21.6 per cent between 1998 and 2007. The regression results indicate that regions benefit from FDI only if their own R\&D stock is high enough.

Another surprising observation with regard to the FDI variables is that the positive and significant FDI spillover effect disappears if the interaction term between $R \& D$ and FDI is introduced into the model (see the difference between Col.3 and Col.4 in Table 1). This will be further discussed in the subsequent section regarding the interaction term between R\&D and FDI $\left(r d e_{t-1} * f d i_{t-1}\right)$.

The interregional FDI spillovers ( $\left.f d i s_{t-1}\right)$ are significant but negative after 1998. Our interpretation of this finding is that there are resource movements and employment flows toward to nearby regions where much foreign investment occurred, which is similar to the "market-stealing effect" discussed in Aitken and Harrison (1999) ${ }^{28}$. FDI invested in one region can attract (or steal) labour and/or other resources from its neighbours.

The year-break effect can be further explained by one important reform, the Hukou system reform, which took place in China exactly in 1998. It is well-known that the strict Chinese Hukou system has prevented labourers from moving for decades. To meet the needs of the transition from a planned to a market economy and the further development of China, the relaxation of Hukou system started in 1990s, first with a couple of regions, i.e. Shanghai in 1994, Shenzhen in 1996 and Guangdong 1998. The official national Hukou reform regulation was issued by the State Council on July 22, 1998. Following that and some other further policy changes in some regions, the rural migrant labour force increased to about 140 million by 2008 (Chan 2010; Pan, 2012). For instance, in Shenzhen, which is located in the south of Guangdong and the first city of five Special Economic Zones in China, migrant labour accounted for 80 per cent of its total labour force in 2000 (Chan, 2009) ${ }^{29}$. The Hukou reforms greatly facilitated labour mobility, and consequently, this allows for labour and resource

\footnotetext{
${ }^{28}$ Aitken and Harrison (1999) find that domestic enterprises receive a negative spillover from foreign enterprises, which they explain as a market-stealing effect.

${ }^{29}$ In 2000, Shenzhen's total population was 7 million, while the registered inhabitants with local Hukou were only 1.3 million.
} 
movements to regions with lots of FDI and causes the negative interregional FDI spillovers.

\section{$\underline{\text { The interaction term between R\&D and FDI }}$}

As stated above, there is a positive and significant effect of direct international FDI spillovers $\left(\right.$ fdis $\left._{t-1}\right)$ after 1998, if the interaction term between R\&D and FDI is introduced in Table 1. In order to examine this issue further, we exclude the nonsignificant fdi variable of Table 1, Col. 4 in the regression of Col.1 of Table 2. The significant and positive coefficient of R\&D and FDI interaction term $\left(r d e_{t-1} * f d i_{t-1}\right)$ after 1998 shows that there is significant interaction between FDI and local R\&D stock. This means that the contribution of FDI, if any, will be captured by the interaction term between R\&D stock and FDI $\left(r d e_{t-1} * f d i_{t-1}\right)$. In other words, this suggests that FDI contributes to the industrial value added in regions which have higher R\&D stocks. If the regional R\&D stock is high enough in a given region, then increases in FDI will have positive effects on output growth. This also explains why Qi et al. (2009) find significant positive spillover effect only in few regions, such as Shanghai, Jiangsu, Guangdong and Beijing, where the domestic R\&D capacity is indeed high.

Domestic innovation capacity is crucial in utilizing foreign spillovers, not only at regional level, but also at sectoral level. Domestic R\&D capacity in one sector also plays an important role to absorb FDI spillovers in this sector. This explains why Jiang et al. (2010) find significant foreign spillovers to China in the telecommunication field, given that the telecommunication is one the most advanced sectors in China and there is a well-established telecommunication infrastructure to absorb foreign spillovers.

\section{The interaction term between FDI and indirect FDI spillovers}

In the model of Col. 2 in Table 2, the interaction term between FDI and indirect FDI spillovers $\left(f d i_{t-1} * f d i s_{t-1}\right)$ is included together with $\mathrm{R} \& \mathrm{D}, \mathrm{R} \& \mathrm{D}$ spillovers and 
indirect FDI spillovers ${ }^{30}$. The coefficients of R\&D ( $\left.r d e_{t-1}\right)$ and R\&D spillover $\left(r d s e_{t-1}\right)$ are similar to those in Table 1. Despite the negative coefficient of $f d i s_{t-1}$, it is interesting that the interaction term between FDI and indirect FDI spillovers $\left(\right.$ fdi $_{t-1} *$ fdis $\left._{t-1}\right)$ is positively significant in the later period, after 1998.

The positive contribution of this interaction term can be interpreted in two ways: on the one hand, if one region has high FDI spillovers from its neighbours, this region is more likely to benefit from direct FDI invested in this region. On the other hand, if one region's FDI level is high, then the FDI spillovers from neighbouring regions can contribute positively to this growth of industrial value added in this region. The former explanation shows again that direct FDI spillovers are conditional, depending on its environment. The later explanation suggests the conditional contribution of indirect FDI spillovers. Namely, FDIS normally contributes negatively, but under certain conditions, i.e. if the local FDI level is high enough, then FDIS can contribute positively. No matter in which situation, it indicates that one region's foreign investment environment is of importance for absorbing technological spillovers from FDI (or FDI in neighbouring regions).

\section{Interaction term between $R \& D$ and indirect FDI spillovers}

In order to further explore the dynamics of indirect FDI spillovers, we include the interaction term between R\&D and indirect FDI spillover $\left(r d e_{t-1} * f d i s_{t-1}\right)$ in the last model (Col.3) in Table 2. Similar to other models in Table 2, we drop the variables which are non-significant in both periods. The sign of the coefficient of the interaction term is negative and - after 1998 significant. In contrast to international direct FDI spillovers $\left(f d i_{t-1}\right)$, interregional indirect FDI spillovers $\left(f d i s_{t-1}\right)$ seem to continue to make negative contributions to industrial value added even if the local R\&D level is high (see the negative coefficients of $r d e_{t-1} * f d i s_{t-1}$ ). So, the interregional effects of FDI are negative.

\footnotetext{
${ }^{30}$ The variable of FDI is taken out from this last model, because of its insignificance.
} 


\section{Conclusions}

This paper explores the impact of technological spillovers on the growth of industrial output in Chinese regions in the period 1990-2005. Our empirical analysis focuses on three types of technological spillovers, interregional R\&D spillovers, international (direct) FDI spillovers and interregional (indirect) FDI spillovers. We also focus on the role of intraregional domestic investment in research and development. Our findings can be summarized as follows.

1. China is the largest recipient of inflows of FDI in the developing world. FDI inflows increased dramatically from 1990 till 1998, tapering off afterwards. Just when the inflow of FDI started to grow more slowly, domestic R\&D investment took off, growing at a rate of 21.6 per cent between 1998 and 2007. One might say that after 1998 , domestic R\&D took over from FDI as a driver of technological advance and technology spillovers.

2. Both R\&D and FDI are highly concentrated in certain regions, with FDI even more concentrated than R\&D. This makes the questions about interregional technology spillovers more relevant than ever. Six regions (Beijing, Shanghai, Guandong, Jiangsu, Sichuan and Shaanxi) accounted for 60 per cent of all R\&D in 1998. Both in 1990 and in 2005, five regions accounted for 70 per cent of all FDI.

3. Over time there have been interesting geographic shifts. In terms of FDI, the role of Guandong become much less prominent. In terms of R\&D intensity, in the earlier years there were inland regions in middle China with high R\&D intensities. Over time, R\&D intensity shifted towards the coast. FDI intensity was highest in the coastal regions all through the period of analysis.

4. Our empirical analysis indicates that there is a clear break in 1998. The contributions to regional growth of almost all variables (capital, labour, R\&D stock, R\&D spillovers, direct FDI spillovers and indirect FDI spillovers) vary greatly between the period before 1998 and the period after 1998. 1998 is the year during which the Hukou system was reformed. After 1998 the growth of FDI slowed down, 
while the growth of R\&D investment took off. Ignoring the structural break would lead to wrong conclusions.

5. The regional R\&D stock contributes significantly and positively to the value added growth of regional industry in almost all cases. Interregional R\&D spillovers are significant and positive in the later period, after the break year 1998. Given that high $\mathrm{R} \& \mathrm{D}$ intensity regions are not located exclusively in the coastal regions but also in the middle of China, this seems beneficial to a great number of regions to catch up.

6. As the biggest FDI recipient in the world, China does not benefit from foreign spillovers unconditionally. Despite huge increases in inward FDI to China since 1990, the positive contribution of direct international FDI spillovers to industrial growth took place only after 1998. The conditional contribution of FDI spillovers is embodied in the interaction between local R\&D and FDI. Regions benefit from direct FDI spillovers only if the local R\&D stock is sufficiently high. In other words, a region will only profit from international FDI spillovers if it has enough technological capacity to absorb foreign FDI spillovers. Phrased differently, our analysis shows that the effect of FDI on growth of output is not the same for all regions but is more likely to be more important in regions where the level of the R\&D stock is high. If a given region's local $R \& D$ is at a sufficiently high level, then the combination of local $R \& D$ and foreign investment can contribute positively to this region's industrial growth. The conditional contribution of FDI spillovers is also embodied in the interaction between direct FDI and indirect FDI spillovers. In other words, if a given region has high FDI spillovers from its neighbours, this region is more likely to benefit from direct FDI flowing into this region.

All the evidence in this paper indicates that sustaining/increasing high level of foreign direct investment doesn't automatically drive the growth of Chinese industry. Whether or not a region benefits from FDI spillovers depends on its absorptive capacity based on its own R\&D efforts and a conducive environment of neighbouring regions with high levels of FDI.

7. With regard to the interregional (indirect) FDI spillovers, our results show that regions cannot expect to benefit from foreign direct investment received by their 
neighbours. On the contrary, due to the movement of labour and other resources towards regions with more FDI, a high level of foreign investment in one region can negatively influence its neighbour's industrial output. FDI acts as a magnet to attract skilled labour. The increase of labour mobility after the Hukou reform seems to accelerate this type of negative indirect FDI spillovers. Our results also indicate that otherwise than in the case of direct FDI spillovers, a high level of local R\&D does not facilitate positive interregional indirect FDI spillovers.

8. In summary, we conclude that the growth of industrial value added in Chinese regions relies mainly on the regional $R \& D$ expenditure, interregional $R \& D$ spillovers and conditional direct FDI spillovers. Indirect interregional FDI spillovers are negative. Considering the distribution of R\&D intensity and FDI intensity across regions - high R\&D intensity in both coastal and middle regions, FDI primarily found in coastal regions - interregional R\&D spillovers seem to contribute more to regional convergence, while FDI and interregional indirect FDI spillovers tend to promote regional divergence.

\section{References}

Abramovitz, M., 1986. Catching up, forging ahead, and falling behind. Journal of Economic History 46, 385-406.

Aiello, F., Cardamone, P., 2005. R\&D spillovers and productivity growth: evidence from Italian manufacturing microdata. Applied Economics Letters 12, 625-631.

Aitken, B.J., Harrison, A.E., 1999. Do domestic firms benefit from direct foreign investment? Evidence from Venezuela. American Economic Review 89, 605-618.

Balasubramanyam, V.N., Salisu, M., Sapsford, D., 1996. Foreign direct investment and growth in EP and IS countries. The Economic Journal 106, 92-105.

Baumont, C., Ertur C., Le Gallo, J., 2000. Geographic spillover and growth: A spatial econometric analysis for European regions. LATEC-Document de travailEconomie, No. 2000-07.

Bernstein, J.I., Nadiri, M.I., 1989. Research and development and intra-industry spillovers: an empirical application of dynamic duality. Review of Economic Studies 56, 249-269. 
Branstetter, L.G., Feenstra, R.C., 2002. Trade and foreign direct investment in China: a political economy approach. Journal of International Economics 58, 335-358.

Buckley, P.J., Wang, C., Clegg, J., 2007. The impact of foreign ownership, local ownership and industry characteristics on spillover benefits from foreign direct investment in China. International Business Review 16, 142-158.

Buckley, P.J., Clegg, J., Wang, C., 2002. The impact of inward FDI on the performance of Chinese manufacturing firms. Journal of International Business Studies 33, 637-655.

Chan, K.W., 2009. Measuring the urban millions. China Economic Quarterly, 21-26, March.

Chan, K. W., 2010. The household registration system and migrant labor in China: Notes on a debate. Population and Development Review 36, 357-364.

Cheung, K., Lin, P., 2004. Spillover effects of FDI on innovation in China: evidence from the provincial data. China Economic Review 15, 25-14.

Caniëls, M., Verspagen, B., 2001. Barriers to knowledge spillovers and regional convergence in an evolutionary model. Journal of Evolutionary Economics 11, 307-329.

Chow, G. C., 1993. Capital formation and economic growth in China. Quarterly Journal of Economics, August, 909-842.

Coe, D.T., Helpman, E., 1995. International R\&D spillovers. European Economic Review 39, 859-887.

Cohen, W.M., Levinthal, D.A., 1989. Innovation and learning: The two faces of R\&D. The Economic Journal 99, 569-596.

Cohen, W.M., Levinthal, D.A., 1990. Absorptive capacity: a new perspective on learning and innovation. Administrative Science Quarterly 35, 128-152.

Dosi, G, Freeman, C., Nelson, R., Silverberg G., Soete L. (Eds), 1998. Technical Change and Economic Theory. Printer Publishers, London.

Ertur, C., Le Gallo, J., Baumont, C., 2006. The European regional convergence process, 1980-1995: do spatial regimes and spatial dependence matter? International Regional Science Review 29, 3-34.

Fagerberg, J., Verspagen, B., 2002. Technology-gaps, innovation-diffusion and transformation: An evolutionary interpretation. Research Policy 31, 1291-1304. 
Funke, M., and Niebuhr A., 2005. Regional geographic research and development spillovers and economic growth: evidence from West Germany. Regional Studies 39, 143-153.

Gao, T., 2004. Regional industrial growth: evidence from Chinese industries. Regional Science and Urban Economics 34, 101-124.

Gerschenkron, A., 1962. Economic Backwardness in Historical Perspective, Harvard University Press, Cambridge Massachusetts.

Girma, S., 2005. Absorptive capacity and productivity spillovers from FDI: a threshold regression analysis. Oxford Bulletin of Economics and Statistics 67, 281-306.

Girma, S., Wakelin, K., 2001. Regional underdevelopment: is FDI the solution: A semiparametric analysis. GEP Workign Paper, 2001/14, University of Nottingham.

Girma, S., Wakelin, K., 2002. Are there regional spillovers from FDI in the UK? in: Greenaway, D., Upward R., Wakelin K. (Eds), Globalisation and Labour Markets. Macmillan: Basingstoke.

Girma, S., Wakelin, K., 2007. Local productivity spillovers from foreign direct investment in the U.K. electronics industry. Regional Science and Urban Economics 37, 399-412.

Girma, S., Greenaway D., Wakelin, K., 2001. Who benefits from foreign direct investment in the UK? Scottish Journal of Political Economy 48, 119-133.

Glass, A. J., Saggi, K., 1998. International technology transfer and the technology gap. Journal of Development Economics 55, 369-398.

Griffith, R., Redding, S., Van Reenen, J., 2004. Mapping the two faces of R\&D: productivity growth in a panel of OECD industries, The Review of Economics and Statistics 86, 883-895.

Griliches, Z., 1979. Issues in assessing the contribution of research and development to productivity growth. The Bell Journal of Economics 10, 92-116.

Griliches, Z., 1990. Patent statistics as economic indicators: A survey. Journal of Economic Literature 28, 1661-1707.

Griliches, Z., 1992. The search for R\&D spillovers, The Scandinavian Journal of Economics 94, Supplement, S29-S47.

Groenewold, N., Lee, G., Chen, A., 2006. Regional output spillovers in China: Estimates from a VAR model. Papers in Regional Science 86, 101-122. 
Hale, G., Long, C., 2006. Firm ownership and FDI spillovers in China. Federal Reserve Bank of San Francisco Working Paper Series, Working Paper 2006-25.

Hale, G. Long, C., 2011. Are there productivity spillovers from foreign direct investment in China? Pacific Economic Review, Vol.16, 135-153.

Hall, B.H., Mairesse J., Mohnen, P., 2010. Measuring the returns to R\&D, in Hall B.H., Rosenberg, N. (Eds), Handbook of the Economics of Innovation - Vol. II. Burlington: Academic Press, 1033-1082.

Harberger, A., 1978. Perspectives on capital and technology in less developed countries, In Artis M. J., Nobay, A.R. (Eds), Contemporary Economic Analysis. Croom Helm, London.

Haskel, J.E., Pereira, S.C., Slaughter, M. J., 2002. Does inward foreign direct investment boost the productivity of domestic firms? NBER Working Paper Series, No. 8724.

Holz, C. A., 2006. New capital estimates for China. China Economic Review 17, $142-185$.

Hu, A.G.Z., Jefferson, G.H., 2002. FDI impact and spillover: evidence from China's electronic and textile industries. The World Economy 25, 1063-1076.

Hu, A.G.Z., Jefferson, G.H., 2004. Returns to Research and Development in Chinese industry: Evidence from State-Owned Enterprises in Beijing. China Economic Review 15, 86-107.

Huang, Y., Ren, R., Liu, X., 2002. Capital stock estimates in Chinese manufacturing by perpetual inventory approach. China Economic Quarterly, Vol.1, 377-396.

Ito, B., Yashiro, N., Xu, Z., Chen, X., Wakasugi, R., 2012. How do Chinese industries benefit from FDI spillovers? China Economic Review, Vol.23, 342-356.

Jacob, J., Szirmai, A., 2007. International knowledge spillovers to developing countries: the case of Indonesia. Review of Development Economics 11, 550565.

Jiang, R., Cai, H., Li, Y., Li, H., 2010. China's sustained economic growth: Do direct R\&D spillovers matter? China \& World Economy 18, 37-53.

Keller, W., 2002. Geographic localization of international technology diffusion, American Economic Review 92, 120-142.

Liu, X., Parker, D., Vaidya, K., Wei, Y.,2001. The impact of foreign direct investment on labour productivity in the Chinese electronics industry. International Business Review 10, 421-439. 
Liu, Z., 2002. Foreign direct investment and technology spillover: evidence from China. Journal of Comparative Economics 30, 579-602.

Liu, Z., 2008. Foreign direct investment and technology spillovers: Theory and evidence. Journal of Development Economics 85, 176-193.

Liu, X., Buck, T., 2007. Innovation performance and channels for international technology spillovers: Evidence from Chinese high-tech industries. Research Policy 36, 355-366.

Liu, X., Wang, C., 2003. Does foreign direct investment facilitate technological progress? Evidence from Chinese industries. Research Policy 32, 945-953.

López-Bazo, E., Vayá, E., Artís, M., 2004. Regional externalities and growth: evidence from European regions. Journal of Regional Science 44, 43-73.

Los, B., Verspagen, B., 2000. R\&D spillovers and productivity: Evidence from U.S. manufacturing microdata. Empirical Economics 25, 127-148.

Madariaga, N., Poncet, S., 2007. FDI in Chinese cities: Spillovers and impact on growth. The world Economy 30, 837-862.

Mohnen, P., 1996. R\&D externalities and productivity growth. STI Review 18, 3966.

Orlando, M.J., 2004. Measuring spillovers from industrial R\&D: on the importance of geographic and technological proximity. Rand Journal of Economics 35, 777786.

Pan, Y., 2012. The positive effect of labor mobility restrictions on human capital accumulation in China. Job Market Paper, (available at http://home.gwu.edu/ panyao/files/Yao\%20Hukou.pdf).

Qi, J., Zheng, Y., Laurenceson, J., Li, H., 2009. Productivity spillovers from FDI in China: Regional differences and threshold effect. China \& World Economy 17, $18-35$.

Raut, L.K., 1995. R\&D spillovers and productivity growth: evidence from Indian private firms. Journal of Development Economics 48, 1-23.

Szirmai, A., 2012. Explaining success and failure in development, in: Rao, D.S. P., van Ark, B. (Eds), World Economic Performance: Past, Present and Future. Cheltenham, Elgar, Chapter 9.

Verspagen, B., 1991. A new empirical approach to catching up or falling behind. Structural Change and Economic Dynamics 2, 359-380. 
Szirmai, A., Ren, R., 2007. Measuring labour productivity in Chinese manufacturing: Statistical problems and solutions, in: Blades, D., Pant, B. (Eds), The National Accounts of the People's Republic of China: Problems, Recent Developments and the Way Forward. Metro Manila, Philippines: Asian Development Bank.

UNIDO. 2012. Structural Change, Poverty Reduction and Industrial Policy in the BRICS, Szirmai, A., Naudé, W., Haraguchi, N., (Eds), UNIDO and UNU-MERIT, Vienna, 2012 (179).

Verspagen, B., 1991. A new empirical approach to catching up or falling behind. Structural Change and Economic Dynamics 2, 359-380.

Verspagen, B., 2001. Economic growth and technological change: An evolutionary interpretation. OECD, STI Working Papers, 2001/1.

Wang, L., Szirmai, A., 2008. Productivity Growth and Structural Change in Chinese Manufacturing, 1980-2002. Industrial and Corporate Change 17, 841-874.

Wang, L., Szirmai, A., 2012. Capital inputs in the Chinese economy: Estimates for the total economy, industry and manufacturing. China Economic Review 23, 81-104.

Wang, L., Szirmai, A., 2013. The Unexpected Convergence of Regional Productivity in Chinese Industry. Oxford Development Studies 41, 29-53.

Wei, Y., Liu, X., 2006. Productivity spillovers from R\&D, exports and FDI in China's manufacturing sector. Journal of International Business Studies 37, 544-557.

$\mathrm{Wu}, \mathrm{H} . \mathrm{X} ., \mathrm{Xu}, \mathrm{X} ., 2002$. Measuring the capital stock in Chinese industry Conceptual issues and preliminary results. Paper prepared for the 27th General Conference of International Association for Research in Income and Wealth. Stockholm, Sweden, August 2002.

Zhang, Q., Felmingham, B., 2002. The role of FDI, exports and spillover effects in the regional development of China. Journal of Development Studies 38, 157-178. 
Annex:

Table A.1: Determinants of Regional Gross Domestic Product, 1950-2005 Estimates of R\&D, R\&D spillovers and FDI spillovers year dummy models

\begin{tabular}{|c|c|c|c|c|}
\hline & $\begin{array}{c}R \& D \text { and } R \& D \text { spillovers } \\
\text { (1) }\end{array}$ & $\begin{array}{l}\text { FDI spillovers } \\
\text { (2) }\end{array}$ & $\begin{array}{l}\text { All } \\
\text { (3) }\end{array}$ & $\begin{array}{l}\text { all with interaction } \\
\text { term rde*fdi } \\
\text { (4) }\end{array}$ \\
\hline \multirow[t]{2}{*}{$k_{t-1 / 2}, \mathrm{t}<1998$} & $0.389 * * *$ & $0.468 * * *$ & $0.415 * * *$ & 0.415 ** * \\
\hline & $(\odot .0755)$ & $(\odot .0748)$ & $(\odot . \odot 89)$ & $(\odot .0881)$ \\
\hline \multirow{2}{*}{$k_{t-1 / 2}, t>=1998$} & $0.695 * * *$ & $0.638 * * *$ & 0.687 ** * & $0.685 * * *$ \\
\hline & $(0.0848)$ & $(0.0811)$ & $(0.101)$ & $(0.101)$ \\
\hline \multirow{2}{*}{$l_{t}, \mathrm{t}<1998$} & $0.604 * * *$ & $0.577 * * *$ & 0.574 ** * & $0.573^{* * *}$ \\
\hline & $(0.0503)$ & $(0.0413)$ & $(\odot .0559)$ & $(0.0549)$ \\
\hline \multirow{2}{*}{$l_{t}, \mathrm{t}>=1998$} & $0.358^{* * *}$ & $0.416 * * *$ & $0.344^{* * *}$ & 0.347 ** * \\
\hline & $(0.0463)$ & $(0.0409)$ & $(0.0512)$ & $(0.0516)$ \\
\hline \multirow{2}{*}{$r d e_{t-1}, \mathrm{t}<1998$} & 0.0991 ** & & $0.105^{*}$ & $0.101 *$ \\
\hline & $(\odot .0482)$ & & $(0.0547)$ & $(0.0536)$ \\
\hline \multirow{2}{*}{$r d e_{t-1}, \mathrm{t}>=1998$} & 0.0847 & & 0.0934 & $0.0991^{*}$ \\
\hline & $(0.0518)$ & & $(0.0588)$ & $(0.0592)$ \\
\hline \multirow{2}{*}{$r d s e_{t-1}, \mathrm{t}<1998$} & $(0.0533$ & & -0.0398 & -0.0602 \\
\hline & $(0.0672)$ & & $(\odot .0768)$ & $(\odot .0771)$ \\
\hline \multirow[t]{2}{*}{$r d s e_{t-1}, \mathrm{t}>=1998$} & 0.0227 & & 0.0415 & 0.0194 \\
\hline & $(0.0634)$ & & $(0.0739)$ & $(0.074)$ \\
\hline \multirow{2}{*}{$f d i_{t-1}, t<1998$} & & 0.000633 & 0.000811 & -0.00621 \\
\hline & & $(\odot .00134)$ & $(\odot .00119)$ & $(\odot . \odot \odot 415)$ \\
\hline \multirow[t]{2}{*}{$f d i_{t-1}, \mathrm{t}>=1998$} & & $0.00665 * * *$ & $0.00543 * * *$ & 0.00545 \\
\hline & & $(\odot .00162)$ & $(0.00165)$ & $(0.00778)$ \\
\hline \multirow[t]{2}{*}{ fdis $_{t-1}, \mathrm{t}<1998$} & & 0.000595 & 0.0000326 & -0.0000483 \\
\hline & & $(0.00254)$ & $(0.00312)$ & $(0.00323)$ \\
\hline \multirow{2}{*}{ fdis $_{t-1}, \mathrm{t}>=1998$} & & -0.000769 & $-0.00859 * *$ & -0.00894 ** \\
\hline & & $(0.00311)$ & $(0.00362)$ & $(\odot .00372)$ \\
\hline \multirow{2}{*}{$r d e_{t-1} * f d i_{t-1}, \mathrm{t}<1998$} & & & & $0.00101 *$ \\
\hline & & & & $(\odot . \odot \odot \odot 563)$ \\
\hline \multirow[t]{2}{*}{$r d e_{t-1} * f d i_{t-1}, t>=1998$} & & & & 0.0000182 \\
\hline & & & & $(0.000923)$ \\
\hline Prob $>F$ & 0.0000 & 0.0000 & 0.0000 & 0.0000 \\
\hline Centered R2 & 0.9585 & 0.9570 & 0.9602 & 0.9606 \\
\hline Uncentered R2 & 0.9585 & 0.9570 & 0.9602 & 0.9606 \\
\hline $\mathrm{N}$ & 464 & 464 & 464 & 464 \\
\hline
\end{tabular}

Note: Dependent variable is industrial value added. Fixed effect models, Robust standard errors are in parentheses. ${ }^{* * *}$ at 1 per cent significance level; $* *$ at 5 per cent significance level; and $*$ at 10 per cent significance level. 
Table A.2: Determinants of Regional Gross Domestic Product, 1990-2005 Estimates of R\&D, R\&D spillovers and FDI spillovers with interaction terms year dummy models

\begin{tabular}{|c|c|c|c|}
\hline & $\begin{array}{l}\text { interaction term rde*fdi } \\
\text { (1) }\end{array}$ & $\begin{array}{l}\text { interaction term } f d{ }^{*} f d i s \\
\text { (2) }\end{array}$ & $\begin{array}{l}\text { interaction term rde*fdis } \\
\text { (3) }\end{array}$ \\
\hline$k_{t-1 / 2}, \mathrm{t}<1998$ & $\begin{array}{l}0.406 * * * \\
(0.0902)\end{array}$ & $\begin{array}{c}0.404 * * * \\
(0.069)\end{array}$ & $\begin{array}{l}0.396 * * * \\
(0.0689)\end{array}$ \\
\hline$k_{t-1 / 2}, t>=1998$ & $\begin{array}{c}0.684 * * * \\
(0.101)\end{array}$ & $\begin{array}{l}0.679 * * * \\
(0.0765)\end{array}$ & $\begin{array}{l}0.710 * * * \\
(0.0762)\end{array}$ \\
\hline$l_{t}, \mathrm{t}<1998$ & $\begin{array}{l}0.575^{* * *} \\
(0.0564)\end{array}$ & $\begin{array}{c}0.571 * * * \\
(0.042)\end{array}$ & $\begin{array}{l}0.613 * * * \\
(0.0426)\end{array}$ \\
\hline$l_{t}, \mathrm{t}>=1998$ & $\begin{array}{l}0.342 * * * \\
(0.0511)\end{array}$ & $\begin{array}{l}0.346 * * * \\
(0.0386)\end{array}$ & $\begin{array}{c}0.353^{* * *} \\
(0.039)\end{array}$ \\
\hline$r d e_{t-1}, \mathrm{t}<1998$ & $\begin{array}{l}0.110 * * \\
(0.0546)\end{array}$ & $\begin{array}{l}0.118 * * * \\
(0.0406)\end{array}$ & $\begin{array}{l}0.117 * * * \\
(0.0398)\end{array}$ \\
\hline$r d e_{t-1}, \mathrm{t}>=1998$ & $\begin{array}{c}0.0935 \\
(0.0593)\end{array}$ & $\begin{array}{l}0.108^{* *} \\
(0.0438)\end{array}$ & $\begin{array}{c}0.117 * * * \\
(0.044)\end{array}$ \\
\hline$r d s e_{t-1}, \mathrm{t}<1998$ & $\begin{array}{l}-0.0448 \\
(0.0772)\end{array}$ & $\begin{array}{l}-0.0188 \\
(0.0587)\end{array}$ & $\begin{array}{l}-0.0296 \\
(0.0587)\end{array}$ \\
\hline$r d s e_{t-1}, \mathrm{t}>=1998$ & $\begin{array}{c}0.0385 \\
(0.0739)\end{array}$ & $\begin{array}{c}0.0681 \\
(0.0569)\end{array}$ & $\begin{array}{c}0.0577 \\
(0.0568)\end{array}$ \\
\hline $\begin{array}{l}\text { fdis }_{t-1}, \mathrm{t}<1998 \\
\text { fdis }_{t-1}, \mathrm{t}>=1998\end{array}$ & $\begin{array}{c}-0.000282 \\
(0.00309) \\
-0.00809 * * \\
(0.0036)\end{array}$ & $\begin{array}{l}-0.000519 \\
(0.00257) \\
-0.0120 * * * \\
(0.00365)\end{array}$ & \\
\hline $\begin{array}{l}r d e_{t-1} * f d i_{t-1}, \mathrm{t}<1998 \\
r d e_{t-1} * f d i_{t-1}, \mathrm{t}>=1998\end{array}$ & $\begin{array}{c}0.000181 \\
(0.000152) \\
0.000653^{* * *} \\
(0.000194)\end{array}$ & & \\
\hline $\begin{array}{l}\text { fdi }_{t-1} * \text { fdis }_{t-1}, \mathrm{t}<1998 \\
\text { fdi }_{t-1} * \text { fdis }_{t-1}, \mathrm{t}>=1998\end{array}$ & & $\begin{array}{c}0.0000152 \\
(0.0000767) \\
0.000375 * * * \\
(0.000123)\end{array}$ & \\
\hline $\begin{array}{l}r d e_{t-1} * \text { fdis }_{t-1}, \mathrm{t}<1998 \\
r d e_{t-1} * \text { fdis }_{t-1}, \mathrm{t}>=1998\end{array}$ & & & $\begin{array}{c}0.0000212 \\
(0.00024) \\
-0.000784^{* *} \\
(0.000358)\end{array}$ \\
\hline Prob $>F$ & 0.0000 & $\odot . \odot \odot \odot \odot$ & $\odot .0 \odot \odot \odot$ \\
\hline Centered R2 & 0.9601 & $\odot .9597$ & 0.9590 \\
\hline Uncentered R2 & 0.9601 & 0.9597 & 0.9590 \\
\hline $\mathrm{N}$ & 464 & 464 & 464 \\
\hline
\end{tabular}




\section{The UNU-MERIT WORKING Paper Series}

2013-01Effects of innovation on employment in Latin America by Gustavo Crespi and Ezequiel Tacsir

2013-02 Revisiting the porter hypothesis: An empirical analysis of green innovation for the Netherlands George van Leeuwen and Pierre Mohnen

2013-03 Impact of external knowledge acquisition strategies on innovation - A comparative study based on Dutch and Swiss panel data by Spyros Arvanitis, Boris Lokshin, Pierre Mohnen and Martin Wörter

2013-04 Interactive knowledge exchanges under complex social relations: A simulation modelRobin by Cowan and Anant Kamath

2013-05 Innovation systems framework: still useful in the new global context? by Michiko lizuka

2013-06 The importance of intrinsic and extrinsic motivation for measuring IQ by Lex Borghans, Huub Meijers and Bas ter Weel

2013-07 Firms' innovation capability-building paths and the nature of changes in learning mechanisms: Multiple case-study evidence from an emerging economy by Paulo N. Figueiredo, Marcela Cohen and Saulo Gomes

2013-08 A set of time series data labour market stocks and flows for the Netherlands 1980 to 2010 by Manuel Müllers, Joan Muysken and Erik de Regt

2013-09 Designing an optimal 'tech fix' path to global climate stability: R\&D in a multiphase climate policy framework by Adriaan van Zon and Paul A. David

2013-10 Complementarity between internal knowledge creation and external knowledge sourcing in developing countries by Jun Hou and Pierre Mohnen

2013-11Summarizing large spatial datasets: Spatial principal components and spatial canonical correlation by Samyukta Bhupathiraju, Bart Verspagen and Thomas Ziesemer

2013-12 Regional systems of innovation in the Arab region by Samia Satti Osman Mohamed Nour

2013-13 Development and social justice: Education, training and health in Sudan by Samia Satti Osman Mohamed Nour

2013-14 The economic importance and impacts of intellectual property rights (IPRs) in Sudan by Samia Satti Osman Mohamed Nour

2013-15 Overview of knowledge economy in the Arab region by Samia Satti Osman Mohamed Nour

2013-16 The importance (impacts) of knowledge at the macro-micro levels in the Arab Gulf countries by Samia Satti Osman Mohamed Nour

2013-17 Political determinants and impact analysis of using a cable system as a complement to an urban transport system by Diego Escobar-García, Francisco García-Orozco and Carlos Cadena-Gaitán

2013-18 Women entrepreneurs in the informal economy: Is formalization the only solution for business sustainability? By Shyama V. Ramani, Ajay Thutupalli, Tamas Medovarszki, Sutapa Chattopadhyay, Veena Ravichandran

2013-19 Heterogeneity in innovation strategies, evolving consumer preferences and market structure: An evolutionary multi-agent based modelling approach by Salih Çevikarslan 
2013-20 Optimal patent length and patent breadth in an R\&D driven market with evolving consumer preferences: An evolutionary multi-agent based modelling approach by Salih Çevikarslan

2013-21 Innovation and productivity: An update by Pierre Mohnen and Bronwyn H. Hall 2013-22 Fathers' use of parental leave. What do we know? by Nevena Zhelyazkova

2013-23 Eliciting Illegal migration rates through list randomization by David McKenzie and Melissa Siegel

2013-24 How do ICT firms in Turkey manage innovation? Diversity in expertise versus diversity in markets by Semih Akçomak, Erdal Akdeve and Derya Fındık

2013-25 Dynamic models of R\&D, innovation and productivity: Panel data evidence for Dutch and French manufacturing by Wladimir Raymond, Jacques Mairesse, Pierre Mohnen and Franz Palm

2013-26 Centre-based versus home-based childcare by Robert Bauchmüller

2013-27 Microeconometric evidence of financing frictions and innovative activity by Amaresh K Tiwari, Pierre Mohnen, Franz C Palm and Sybrand Schim van der Loeff

2013-28 Innovation for economic performance: The case of Latin American firms by Elena Arias Ortiz, Gustavo Crespi, Ezequiel Tacsir, Fernando Vargas and Pluvia Zuñiga

2013-29 Is money all? Financing versus knowledge and demand constraints to innovation Gabriele Pellegrino and Maria Savona

2013-30 Child deprivation in Ontario - A (less than perfect) comparison with Europe by Geranda Notten

2013-31 Measuring performance: does the assessment depend on the poverty proxy? by Geranda Notten

2013-32 How big is the impact of infrastructure on trade? Evidence from meta-analysis by Mehmet Güney Celbis, Peter Nijkamp and Jacques Poot

2013-33 Using a 'Systems' Perspective to Explain the Limits of 'New' Multinational Enterprises: the role of 'members-only' location advantages by Rajneesh Narula

2013-34 Foreign direct investment as a driver of industrial development: why is there so little evidence? by Rajneesh Narula

2013-35 The end of the multifibre arrangement (MFA) and the heterogeneous performance of quota-constrained countries by Mulu Gebreeyesus

2013-36 Techological capability building in MNE-related social businesses of less developed countries: The experience of Grameen-Danone Foods in Bangladesh by Jahan A. Peerally and Paulo N. Figueiredo

2013-37 The links between economic integration and remittances behaviour of migrants in the Netherlands by Özge Bilgili

2013-38 The influence of vulnerability on migration intentions in Afghanistan by Craig Loschmann and Melissa Siegel

2013-39 How unemployment insurance savings accounts affect employment duration: Evidence from Chile by Paula Nagler

2013-40 Self-organization of knowledge economies by François Lafond

2013-41 Designing an optimal 'tech fix' path to global climate stability: Directed R\&D and embodied technical change in a multi-phase framework by Adriaan van Zon \& Paul A. David

2013-42 The growth of outward FDI and the competitiveness of the underlying economy: the case of India by Rajneesh Narula and Tiju Prasad Kodiyat 
2013-43 The impact of migration on children left behind in Moldova by Franziska Gassmann, Melissa Siegel, Michaella Vanore and Jennifer Waidler

2013-44 Technological spillovers and industrial growth in Chinese regions by Lili Wang, Huub Meijers and Adam Szirmai 